\title{
Arte rupestre en los corregimientos coloniales de Tarapacá y Atacama. Problemáticas comparativas iniciales
}

\section{Colonial rock art in the corregimientos of Tarapacá and Atacama. Initial comparative issues}

\author{
Marco Antonio Arenas C. ${ }^{1}$ https://orcid.org/0000-0001-7615-3597 \\ Bosco González ${ }^{2}$ https://orcid.org/0000-0001-6468-7161 \\ José Luis Martínez C. ${ }^{3}$ https://orcid.org/0000-0001-5276-8036 \\ ${ }^{1}$ Punitaqui 4265, Nuñoa, Santiago, CHILE. Email: marenas131@gmail.com \\ ${ }^{2}$ Investigador adscrito a la Dirección General de Investigación. Vicerrectoría de Investigación, \\ Innovación y Postgrado. Universidad Arturo Prat, Iquique. CHILE. \\ Email: Bosco.gonzalez.jimenez@gmail.com \\ ${ }^{3}$ Universidad de Chile, Centro de Estudios Culturales Latinoamericanos - Departamento de \\ Ciencias Históricas, Santiago, CHILE. Email: jomarcer@u.uchile.cl
}

\section{Resumen}

Se realiza un ejercicio comparativo entre espacios y significantes rupestres coloniales identificados en los corregimientos de Tarapacá y Atacama. Se presentan y describen 36 sitios con arte rupestre colonial y una tabla con el total de significantes visuales identificados en cada sitio. Se propone que los sitios se ubican en espacios que responden a dos modalidades de funcionamiento: por un lado, están asociados a rutas o caminos de mayor o menor importancia que comunicaban distintos enclaves indígenas asociados al poder colonial. Por otro, se propone la existencia de espacios más discretos, muchas veces cercanos a estos mismos caminos, pero de difícil visibilidad y acceso. Con la excepción de un único caso (en el Corregimiento de Atacama), todos los demás funcionaban desde tiempos prehispánicos y siguieron actualizándose en el período colonial. Se aborda la distribución espacialmente desigual de los sitios existentes, y la mayor o menor densidad de registros coloniales que se encuentra en ellos. Se postula que esas diferencias pueden deberse a las características y profundidad de la impronta colonial, a las dinámicas sociales internas a cada comunidad y a las características de los procesos religiosos locales.

Palabras claves: arte rupestre colonial, sociedades andinas, rutas de "circulación" y espacios "discretos".

\begin{abstract}
A comparative exercise between spaces and signifiers from colonial rock art identified in the districts of Tarapacá and Atacama is performed. We describe and discuss 36 sites with colonial rock art and present a table with the total of visual signifiers identified in each site. It is proposed that the sites are in such spaces shows two operating modes: on the one hand, are associated with routes or paths of greater or lesser importance of communicating different indigenous enclaves associated with the colonial power. Furthermore, it is proposed the existence of more discrete spaces, often close to these same roads but of limited visibility and access. Except for a single case (in the Corregimiento de Atacama), all sites were operated since pre-Hispanic times and continued to be used in the Colonial period. The spatially uneven distribution of existing sites, and the greater or lesser density of colonial records found in them is addressed. It is postulated that these differences may be due to the characteristics and depth of the colonial imprint, internal social dynamics of each community and the characteristics of local religious processes.
\end{abstract}

Keywords: colonial rock art, pathways and "discreet" spaces.

Recibido: 23 octubre 2016. Aceptado: 22 abril 2017 
Desde hace ya algunos años, el arte rupestre realizado por las sociedades andinas durante el período colonial, ha ido adquiriendo una mayor visibilidad $y$, a medida que se identifican más sitios en los que se puede registrar su presencia y conocer mejor las temáticas representadas, van surgiendo nuevos problemas y preguntas de investigación (Gallardo, Castro y Miranda,1990; González, 2014; Querejazu, 1992; Taboada, 1988, 1992; Strecker y Taboada, 2004; Hostnig, 2004; Martínez C. y Arenas, 2009; Martínez C., 2009; Arenas, 2011; Arkush, 2014; Berrojalviz, 2015).

En este artículo queremos intentar un primer ejercicio de identificación de los sitios con arte rupestre colonial en lo que fueron los corregimientos coloniales de Tarapacá y Atacama (actuales regiones de Tarapacá y de Antofagasta), en el norte de Chile y de la provincia de Jujuy (en Argentina), ${ }^{1}$ analizando comparativamente los temas y significantes que ellos muestran.

Son escasos los estudios que abordan las panorámicas regionales del arte rupestre colonial, y menos las que comparan dos de ellas. Lo usual ha sido, hasta ahora, la descripción de estas manifestaciones en sitios aislados unos de otros o, cuando más, en espacios más acotados, como una quebrada, un valle o una cuenca hidrográfica. De allí que nos parece interesante intentar este ejercicio, a pesar de las diferencias en la calidad de la información de que disponemos hasta hoy, en la perspectiva de ir identificando nuevas problemáticas no abordadas hasta este momento.

Nuestra convicción es que cada uno de estos sitios formó parte de un sistema comunicativo más amplio que, más allá de variaciones formales en algunos de sus significantes visuales, permitió que circularan temas y enunciados similares. Esos sitios fueron la manifestación de cómo cada pequeña comunidad andina colonial se expresó a través de sus imágenes rupestres, dialogando con sus vecinos y respondiendo a condiciones histórico-sociales comunes, como lo fueron las coloniales.

1 Hasta, al menos, inicios del siglo XIX, una parte de la llamada Puna de Atacama (actualmente en Argentina) dependía del Corregimiento de Atacama, con cabecera en San Pedro de Atacama.
Esto fue posible porque las comunidades andinas locales compartían algunos códigos de significación, así como determinados significantes visuales, sugiriendo fuertemente la existencia de una comunidad de sentido y el uso colectivo del arte rupestre como lenguaje visual y comunicativo, que va más allá de las especificidades históricas propias de cada corregimiento colonial. Se trata de espacios entre los cuales circularon en una y otra dirección las poblaciones de ambos corregimientos (Odone, 1995; Martínez C., 1998).

En el presente trabajo proponemos una discusión preliminar sobre algunos de esos sitios con arte rupestre colonial en estos territorios, utilizando fuentes primarias y secundarias. Nos basamos fundamentalmente en el trabajo de campo desarrollado en Tarapacá por uno de nosotros (González, 2014), y para el caso del antiguo Corregimiento de Atacama contamos con observaciones de campo obtenidas en diversos recorridos realizados a lo largo de varios años, fundamentalmente en la cuenca del río Loa y, más marginalmente, en algunos sitios de la cuenca del salar de Atacama, hechos por los otros dos autores de este trabajo.

Varios de los sitios que presentamos aquí no han sido aún descritos en la bibliografía especializada. Además, incorporamos materiales y descripciones de algunos otros sitios, proporcionados generosamente por nuestros colegas arqueólogos, que realizaron exploraciones más detalladas que las que pudimos efectuar nosotros. Finalmente, también consideramos las descripciones realizadas por otros investigadores, disponibles bibliográficamente.

Dado que se trata de información proveniente de diversas fuentes y los datos son el resultado de procesos de levantamiento metodológicamente heterogéneos, no pretendemos ofrecer una presentación exhaustiva de sitios, sino abrir un debate, plantear preguntas sobre la base del material actualmente disponible y abrir posibilidades de interpretación que le den sustento a nuevas preguntas de investigación e hipótesis comparativas preliminares.

Nos interesa identificar el emplazamiento de algunos sitios y discutir qué tipo de relaciones muestran con los espacios donde pudieron circular discursos asociados al poder colonial. Junto con esto buscaremos 
la(s) relación(es) entre significantes, de uno y otro sitio, que nos puedan sugerir su circulación y las diferentes prácticas comunicativas (de continuidad o de control iconoclasta) que tuvieron lugar en ellos. Un significante que da cuenta de esta doble dimensión es la cruz calvario de base triangular, empleada tanto en contextos de integración entre representaciones prehispánicas y coloniales, como en actividades represivas, de extirpación y destrucción de las antiguas imágenes.

¿Cómo entender los espacios y los sitios de arte rupestre? ¿Es posible disociar uno de otro, es decir espacio y sitio? Nuestro enfoque en la problemática del arte rupestre colonial ha puesto especial atención en la relación imagen y soporte, entendiendo por este último un espacio discreto que se utiliza como continente de una o varias imágenes que pueden funcionar al interior del mismo. Consideraremos, momentáneamente, el recorte metodológico de sitio-panel-motivo como secundario en esta discusión, puesto que nos interesa priorizar la posibilidad de cruzar el análisis de algunos de esos sitios con otras variables espaciales, tales como la construcción o marcas de espacios significantes, su posible vinculación con escenarios políticos y religiosos coloniales y con otras variantes comunicativas, propias de este sistema de comunicación.

En esta misma línea, discutiremos la distribución de los sitios existentes, en la convicción de que el agrupamiento de aquellos con mayores densidades representacionales y la distribución y circulación de determinados conceptos visuales en unos $\mathrm{u}$ otros pueden orientar preguntas de investigación que contribuyan al estudio del pasado colonial de las sociedades andinas del Norte Grande.

De antemano, nos disculpamos con nuestros lectores. La descripción, a veces detallada de los sitios, puede parecer a ratos excesiva o demasiado descriptiva. Esto se debe a una opción que hemos tomado para facilitar la comprensión de algunos aspectos de nuestra discusión. Como lo dijimos, un número importante de estos sitios no ha sido descrito o han sido estudiados parcialmente, dejando fuera los significantes coloniales, para privilegiar los prehispánicos. Esperamos que la tabla que incorporamos en la discusión final facilite el seguimiento de nuestra discusión.

\section{Distribución de los sitios con arte rupestre colonial en los corregimientos de Tarapacá y Atacama. Espacialidades y significantes}

Creemos, siguiendo a G. Martínez (1983) y Cruz (2012), que el espacio topográfico es un conjunto significante construido históricamente que expresa una cierta organización semiótica-semántica, donde cerros, lagunas y pampas pueden ser signos de una textualización más amplia. El arte rupestre se constituye, en este sentido, en uno de los participantes de este proceso de textualización del espacio, por lo cual resulta importante para nosotros exponer aquí la manera en que están dispuestos los sitios con representaciones rupestres coloniales en las unidades espaciales que hemos adoptado para nuestra reflexión, a saber, los corregimientos coloniales de Tarapacá y Atacama. Cabe la aclaración de que el sentido de utilizar los corregimientos es territorial y no circunscribe necesariamente la adscripción cronológica de los materiales en discusión. Es más, muchos de los significantes aquí comentados pueden preceder a la fundación administrativa de alguno de ellos. En esta perspectiva, pasaremos a revisar la presencia de arte rupestre colonial en algunas de las cuencas hidrográficas más importantes que integran dichos corregimientos (Figura 1).

\section{Corregimiento de Tarapacá}

Tarapacá se integra al sistema de administración colonial como tenientazgo del Corregimiento de Arica en el ańo 1565; teniendo como centro del control y asentamiento del corregidor, el pueblo de Pica. Esta situación administrativa se mantuvo hasta la segunda mitad del siglo XVIII, momento en el que, específicamente el año 1767 y por orden del virrey Amat y Juniet, se conforma el Corregimiento de Tarapacá, el cual habría tenido, en palabras del mismo virrey, los siguientes límites territoriales:

Desmembró y separo de la jurisdicción y corregimiento de Arica, la antigua provincia de Tarapacá, erigiéndola como la erijo en gobierno distinto e independiente del citado 


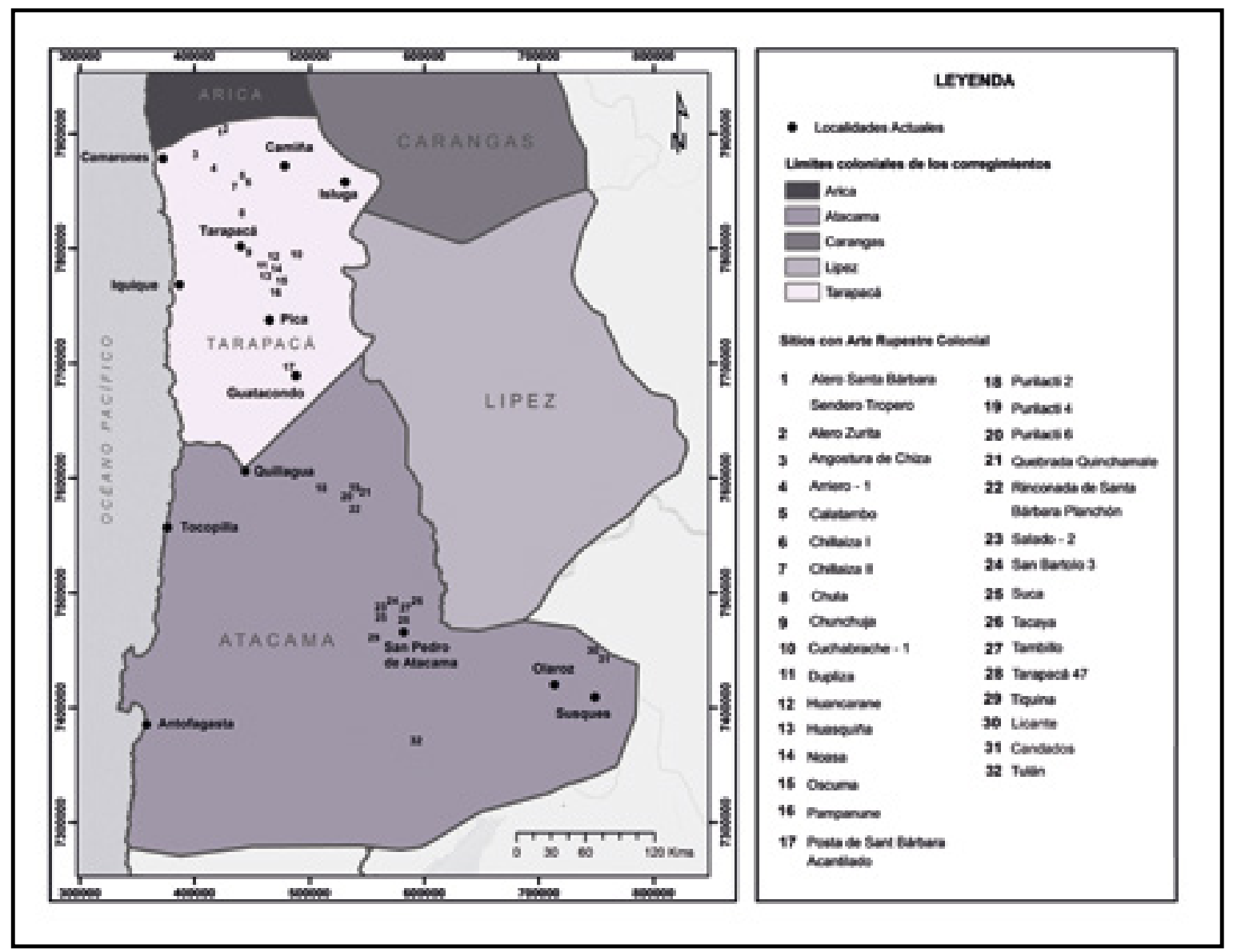

Figura 1. Mapa de los corregimientos coloniales de Tarapacá y Atacama y ubicación de las localidades y los sitios con arte rupestre colonial mencionados en el texto.

corregimiento de Arica, bajo los términos que de ella la deslindan, y de la de Atacama y Lipes, incluyéndose la capital y asiento de Sibaya, Camiña, Mamiña, Pica, Matilla, Guatacondo y los demás principales y anexos con los puertos de Iquique y Pisagua, y los famosos minerales de Huantajaya y Chanabaya, con otros de menor cuenta que están situados y son conocidos en la mencionada provincia de Tarapacá (Amat y Juniet, 1947 [1761-1776]).

Desde el punto de vista del asentamiento de las autoridades eclesiásticas en Tarapacá, es posible afirmar que la primera unidad administrativa la constituyó la Doctrina de Tarapacá, la cual tomó asiento en la antigua aldea del mismo nombre. En la segunda mi- tad del siglo XVI esta unidad eclesiástica se divide en dos curacazgos, el de Chiapa y Tarapacá (Murra, 1980; Advis, 1990; Urbina, 2014), constituyéndose con posterioridad Camiña como una nueva doctrina en lo que fue el Tenientazgo de Tarapacá. En la primera mitad del siglo XVII se constituye el curato de Pica y años más tarde se creará el escenario administrativo eclesiástico con la conformación de Sibaya como un curato doctrinal.

El poblamiento colonial, en este corregimiento, se distribuyó en diferentes cuencas hidrográficas y sectores, no todos los cuales muestran evidencias de arte rupestre colonial. Hasta el momento hemos encontrado registros rupestres en tres de esas cuencas: en las de pampa del Tamarugal, del río Camarones y de Camińa (con sus respectivas subcuencas). En cambio, no los hemos encontrado ni conocemos 
información acerca de registros de datación colonial en el altiplano tarapaqueño ni en el segmento costero que va entre los ríos Tiliviche y Loa, a excepción de un équido registrado en Quillagua en técnica de geoglifo (G. Pimentel, com. pers. a M. Arenas, 2011), lo cual constituye un dato excepcional. No se trata de nada conclusivo, puesto que puede deberse a la falta de una exploración más exhaustiva en ambos sectores.

$\mathrm{Al}$ interior de las tres primeras cuencas, hemos identificado diecisiete sitios con representaciones rupestres coloniales. Dichos sitios se distribuyen de forma diferenciada entre las cuencas hidrográficas y sus subcuencas y quebradas asociadas. La información sobre este corregimiento proviene de un registro directo realizado por uno de los autores, complementado con la bibliografía publicada sobre esos sitios.

\section{Cuenca pampa del Tamarugal}

En esta cuenca, la más extensa de lo que fue el Corregimiento de Tarapacá, se han identificado 10 sitios con representaciones rupestres coloniales. Llama la atención que ocho de ellos se concentran en un espacio muy específico, que va desde la subcuenca Tambillo por el norte a la de Quipisca por el sureste. Esto configura una estructura desigual en la distribución de sitios, ya que existe una alta concentración, asociada al asentamiento prehispánico de Jamajuga (en la actualidad Mamiña), y una menor presencia de sitios en las extensas pampas y quebradas del resto de la cuenca. Esto sin lugar a duda llama nuestra atención y lo abordamos con más detalle en las páginas siguientes.

En la quebrada de Tarapacá, en el sitio Tarapacá 47, es posible observar un único registro identificado como un motivo ecuestre (Núńez y Briones, 1967; Martínez y Arenas, 2011), mientras que en el llano intercuenca, entre la quebrada seńalada y la quebrada de Aroma, hacia el norte, nos encontramos con el sitio de Chintuma / Huasquiña, que posee tres registros, en técnica de geoglifo.

Algo similar ocurre en el sitio Tambillo; en este último se encuentra el sitio homónimo en el cual se identifican tres grabados coloniales (Figura 2). Uno

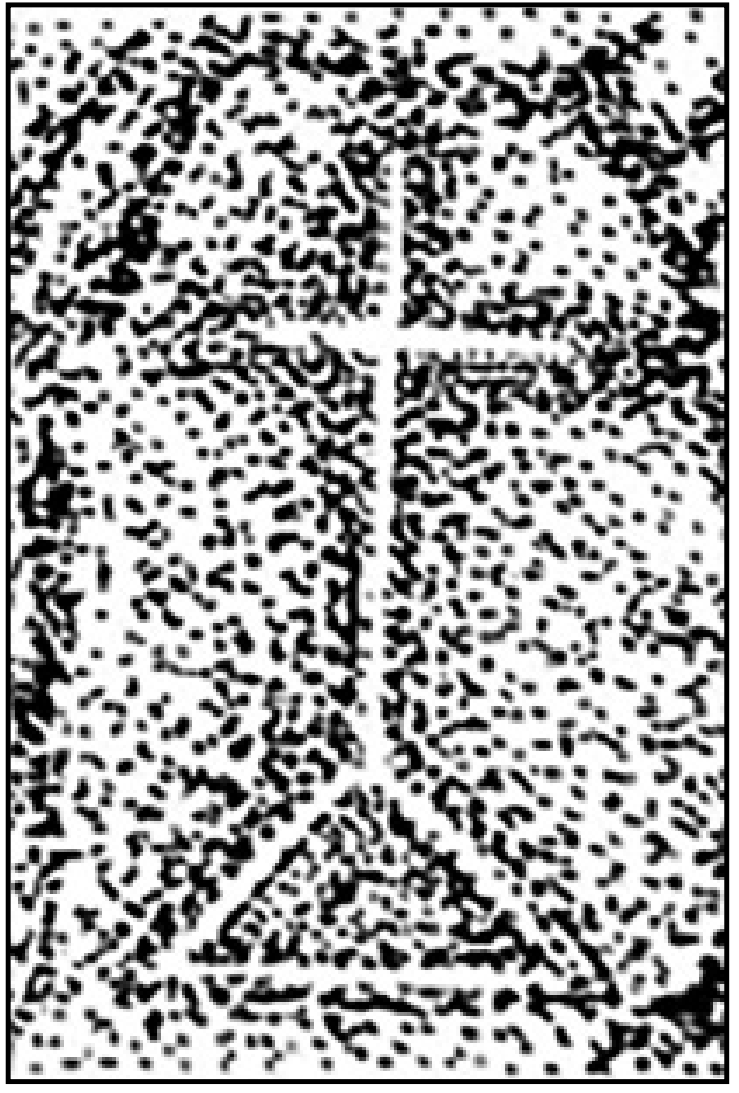

Figura 2. Significantes rupestres coloniales del sitio de Tambillo, cuenca pampa del Tamarugal (según Moragas 1996).

de ellos corresponde a una cruz calvario de base triangular, que parece funcionar en solidaridad diacrónica $^{2}$ (sensu Mege, 2000; Mege y Gallardo, 2006 Ms.) respecto al conjunto significante indígena prehispánico (Moragas, 1996).

Desde nuestra perspectiva, se trata de sitios con una baja densidad representacional (una frecuencia de

2 Siguiendo a estos autores, la relación en una solidaridad diacrónica operaría como una asociación de significantes en relaciones solidarias, pero pertenecientes a diferentes momentos históricos. Lo que hemos venido proponiendo en distintas discusiones (p.e., Martínez C. y Arenas, 2009; Arenas y Odone, 2015), es que el sistema rupestre actúa como receptor de nuevos discursos visuales, en aquellos repositorios de una larga tradición rupestre, sin entrar en conflicto con los discursos precedentes. En este sentido, operaría un cambio de paradigma visual, en un contexto de espacio sacralizado que mantendría su antiguo significado. 
entre uno y tres registros por sitio). Es una condición que se modifica al observar el comportamiento de los registros coloniales ubicados al interior de la quebrada de Quipisca, en los que hemos identificado al menos seis sitios con representaciones rupestres coloniales: Dupliza, Chula, Chunchuja, Noasa, Oscuma y Tacaya.

El repertorio de significantes en estos sitios es bastante acotado; se encuentran fundamentalmente registros religiosos como las cruces latinas y cruces en calvario, la gran mayoría de ellos como grabados. La excepción es Dupliza, donde se encuentran representaciones de arquitectura eclesiástica como campanarios y torres en técnica de geoglifo (Figura 3).

Además de que en esta quebrada se ubica una mayor cantidad de sitios con registros coloniales, su densidad es igualmente mayor: hemos identificado 19 registros. ¿Por qué esa concentración en esta quebrada y no en las otras o en los llanos?

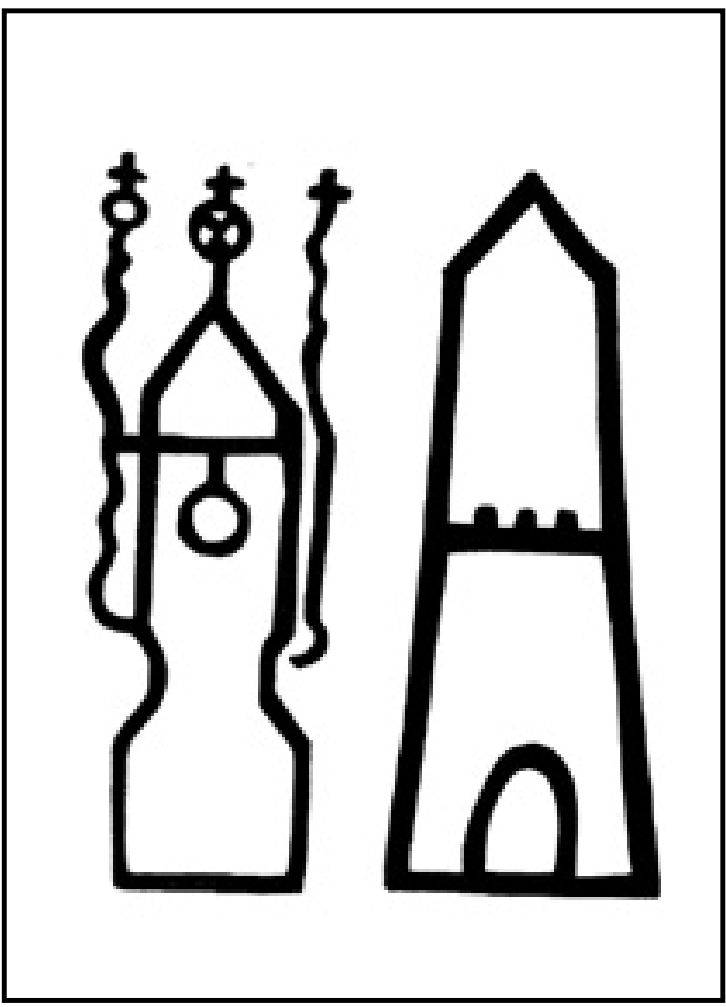

Figura 3. Geoglifos coloniales del sitio de Dupliza, cuenca pampa del Tamarugal

(según Chacama et al. 1992: 171).
Respecto de su ubicación, lo que es igualmente un aspecto significante, algunos de los sitios se encuentran cerca de los caminos que conectan las quebradas al sur de Mamińa, como los casos de las quebradas de Tacaya y de Oscuma, ambas tributarias de la de Macaya. A lo largo de la primera quebrada se encuentran varios sitios con repositorios de arte rupestre de temática prehispánica (grabados geométricos y zoomorfos esquemáticos). Cerca de Jauja, una mina de cobre, Niemeyer señaló un enorme bloque conocido como "Piedra del león", describiendo dos caras planas profusamente grabadas (Niemeyer, 1961, p. 107). En la cara que mira al oriente aparece "hacia el borde inferior de la cara, una cruz compuesta de línea triple, acompañada en un lado de otra crucecita simple" (Niemeyer, 1961, p. 108). La reproducción gráfica del grabado comentado permite reconocer el contorno de una cruz latina y una cruz andina superpuestas, al parecer en solidaridad diacrónica, ${ }^{3}$ con una cruz pequeña "inscrita" concéntricamente (Figura 4).

En el caso de la quebrada de Oscuma, encontramos una cruz en calvario que, si bien no se impone sobre, o anula, los motivos prehispánicos inscritos previamente, transforma el sentido del bloque, dada su posición y tamaño en relación a lo preexistente, caracterizado por la presencia de significantes abstractos (círculos con punto y círculos concéntricos, algunos unidos por trazos lineales) y figuras antropomorfas esquemáticas (Niemeyer, 1961, p. 105).

Parecido es el caso del sitio de Chunchuja, ubicado sobre la cuesta que conduce desde la quebrada homónima a Macaya, también al sur de Mamiña. En este sitio se encuentran algunos bloques pequeños y medianos de liparita con grabados correspondientes

3 Una debilidad metodológica de la presente discusión ha sido la falta de análisis in situ de, por ejemplo, los sitios con significantes coloniales reportados por Niemeyer (1961), en el sentido de contrastar las diacronías y/o sincronías significantes y sus relaciones solidarias, ya sea dentro de una composición o bien funcionando por disposición. Queda a modo de hipótesis su presencia, considerando que las relaciones significantes solidarias, tanto en diacronía como en sincronía, constituirían un principio de funcionamiento del sistema rupestre. Sobre la composición y disposición significante en el arte rupestre, ver la interesante discusión de Gallardo (2009). 


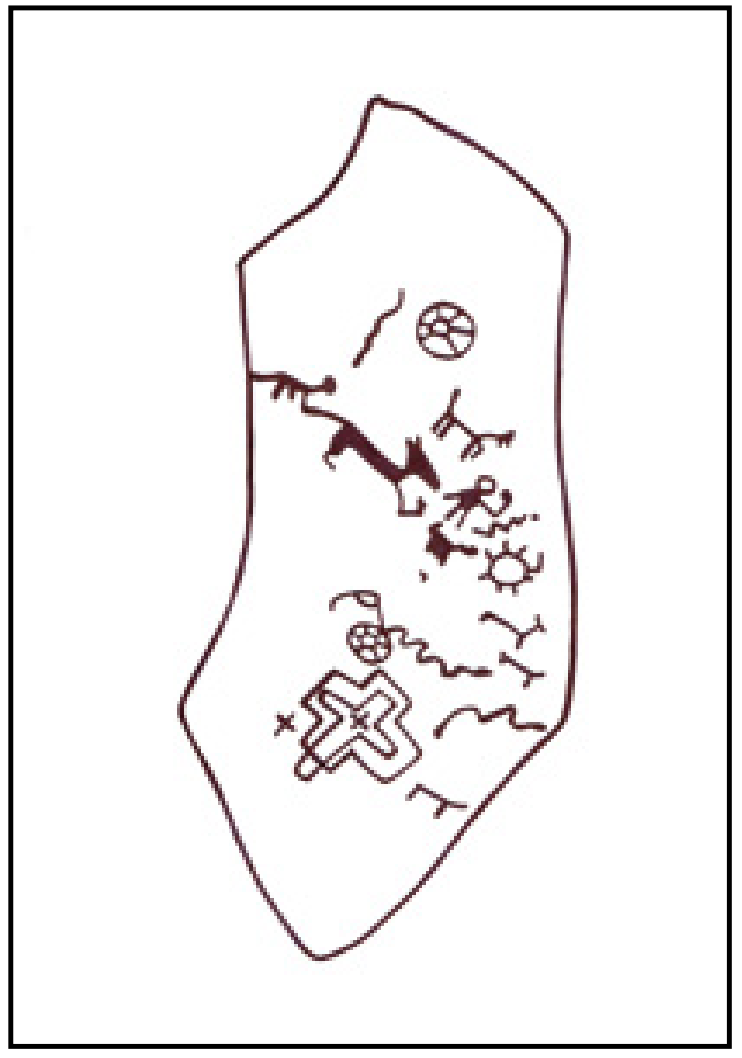

Figura 4. Cruz cristiana y cruz andina compartiendo un mismo espacio, sitio Piedra del León, quebrada de Tacaya, cuenca pampa del Tamarugal (Según Niemeyer 1961: 107).

a significantes abstractos que representan círculos con punto concéntrico y cruces (Niemeyer, 1961). Por su disposición en uno de los conjuntos significantes reportados por Niemeyer (1961, fig. 9), las cruces se encuentran yuxtapuestas a los círculos con puntos concéntricos, constituyendo una expresión más, tal como se observa en muchos lugares de los Andes, de la "convivencia" del pasado prehispánico con el presente colonial en un mismo soporte. Lo que no podemos asegurar, por el tipo de registro, es la contemporaneidad en la ejecución de los significantes. Se trataría de una situación ya documentada por uno de nosotros en el extremo sur de la actual provincia de Atacama, en la que hay varios ejemplos de una ejecución sincrónica de significantes del pasado prehispánico, hechos en ese presente colonial de las poblaciones andinas (Arenas, 2011, 2013).

Para abundar en este tipo de "comportamiento" en senderos y caminos de las quebradas cercanas al sec- tor de Quipisca y Mamińa, anotamos la referencia de Niemeyer (1961, p. 109) sobre un bloque grabado en la quebrada de Chula:

En nuestra segunda excursión a la Sierra, sobre la huella que va desde el Mineral de Jauja al de Pila, en la quebrada secundaria de Chula, constatamos la presencia de un enorme peńasco granítico en cuya cara al Naciente encontramos representaciones realistas muy fieles de auquénidos [sic]; una cruz dentro de un rombo; cruces aisladas; una cruz inscrita en una figura en forma de colmena u ojival; pequeños círculos; dos cruces con sendos pedestales romboidales; $y$ un par de líneas cortas.

El sector de Noasa, segmento alto de la quebrada conocida con este nombre y de Parca y Quipisca en su sector medio e inferior, constituye un complejo agrícola de cabecera de valle con importante presencia de bloques grabados. Aquí Niemeyer identificó un motivo ecuestre de contorno lineal en donde el personaje montado porta un sombrero. Tal como anota el autor, "algunos de los grabados son indudablemente de tiempos postcolombinos, entre los que se cuentan hombres montados o animales domésticos traídos por los conquistadores" (Niemeyer, 1961, p. 111). En este caso, por sus atributos formales, proponemos que este motivo ecuestre responde a una solución representacional más tardía a las identificadas como motivos ecuestres coloniales tempranos; posiblemente entonces, asignable a los siglos XVII o XVIII (Arenas y Martínez, 2009; Gallardo et al., 1990).

Continuando con la cuenca pampa del Tamarugal, encontramos un último sitio llamado Tiquina, que se ubica en el extremo sur de la cuenca, en la zona de Tamentica. Ejecutados en técnica de pintura roja se observan algunos motivos antropomorfos y zoomorfos. Corresponde a un conjunto significante al parecer en solidaridad diacrónica, al observarse motivos de tradición prehispánica con otros de clara factura colonial. Entre estos últimos destaca un motivo ecuestre cuyo arreglo estético (sensu Gallardo et al., 1990) recuerda al antropomorfo frontal sobrepuesto al motivo camélido, pero en este caso 
los atributos de un équido se pronuncian en el cuello corto del animal, el alargamiento del morro u hocico y una cola levemente larga y recta, diferente a las colas quebradas distintivas de los camélidos (Figura 5).

El sitio de Dupliza, cercano a la quebrada de Quipisca, nos proporciona un ejemplo singular de cómo el proceso colonial no implicó la desaparición de las diferentes técnicas asociadas al sistema de arte rupestre andino. Es más, este mismo caso y otros que veremos más adelante, como los de Huasquiña (Chintuma) y Licante, muestran que, para inscribir los nuevos significantes y temas, se emplearon todas las técnicas prehispánicas.

En este sector, entre otros, se han identificado dos significantes coloniales en técnica de geoglifo (Chacam, Briones y Santoro, 1992), en un sector de alto tránsito tanto en sentido longitudinal (p.e., camino del inka) como vertical (transecto Quipisca, Parca, Noasa, Yarbicoya, Lirima y Cancosa).

Es posible asociar las técnicas de pintura y las de grabado, independientemente del contexto sociorritual, a acciones individuales en su ejecución. En la técnica de geoglifo, en cambio, la acción colectiva en su ejecución parece ineludible. Lo que buscamos apuntar es que, con los ejemplos de Dupliza, es posible postular que algunas comunidades continuaron creando y recreando un sistema tan complejo y monumental como el comentado, ya en tiempos coloniales, apelando a prácticas colectivas. Conocemos otro caso que pudiera ser similar, con acciones de conservación y culto en sitios con geoglifos, para tiempos republicanos tempranos, en la pampa de Ica (Bollaert, 1975 [1860]). En el caso de Dupliza se delinearon, sobre la superficie de los cerros que flanquean la quebrada por su lado sur, dos grandes campanarios de iglesias con detalles arquitectónicos

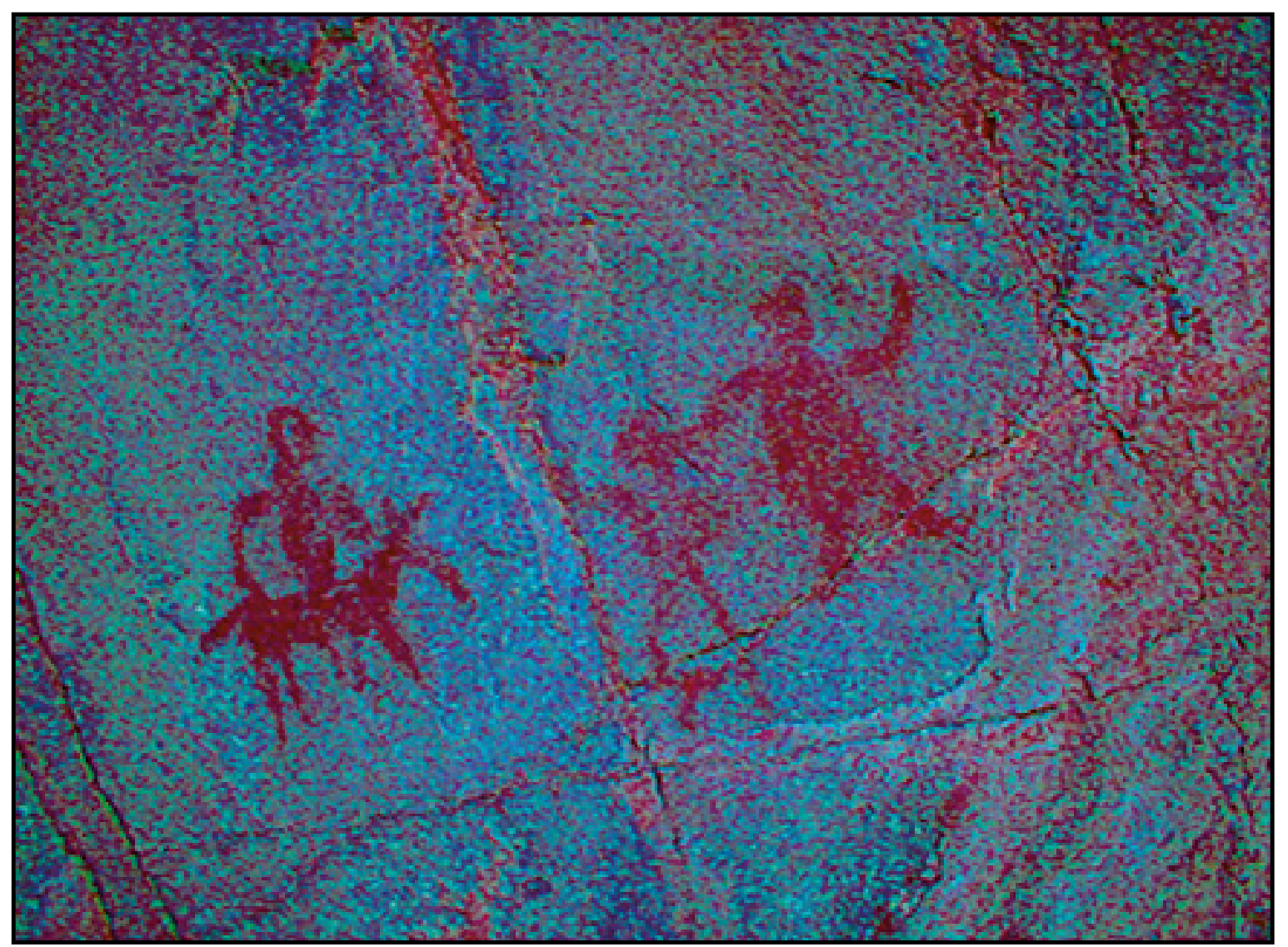

Figura 5. Antropomorfo sobre camélido con atributos de equino. Sitio Tiquina. 

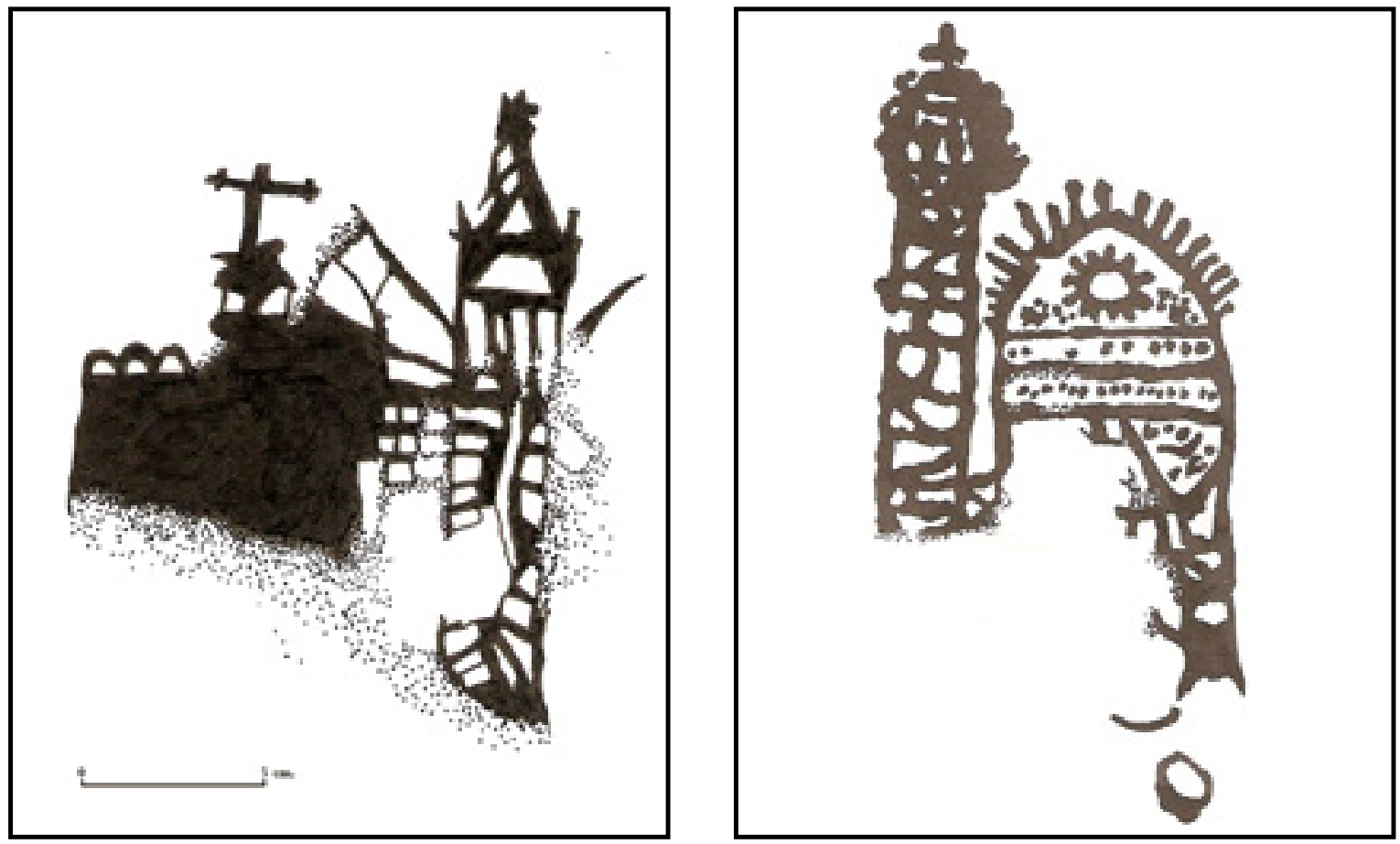

Figura 6 a y b. Iglesia de estilo colonial en el sitio de Chirapaca, Provincia Los Andes, La Paz, Bolivia.

que recuerdan las iglesias y campanarios ejecutados en técnica de pintura del sitio de Chirapaca, al sur del lago Titicaca (Figuras 6a y b). En este sitio las iglesias y campanarios, entre otros motivos, se observan como un material diagnóstico para el sistema rupestre colonial, y ya sea en técnica de pintura o grabado, es posible observar su circulación en el amplio espacio surandino (Martínez y Arenas, 2009). Tal como se ha mencionado más arriba, la apropiación selectiva de significantes coloniales incorporados al sistema de geoglifos también se ha observado en los geoglifos que marcan la ruta en la salida sur del oasis de Quillagua. Aquí G. Pimentel (com. pers. a M. Arenas, 2015) identificó un equino en "contorno lineal", que se diferencia de la técnica de ejecución extractiva o raspado areal (sensu Briones, 1984), dominante en el sector. Un tercer ejemplo lo vemos en los geoglifos de Camiña, en donde se observan un par de calvarios de base escalonada o cuadrada, yuxtapuestos a una hilera de camélidos (González, 2014).

Lo que llama la atención aquí es el principio de solidaridad diacrónica que se ha comentado antes, junto a la apropiación de un conjunto de significantes que son diagnósticos para el período colonial, tales como el caballo, los campanarios y las cruces y que fueron integrados a un espacio visual ya sacralizado, que siguió funcionando en la lógica de las comunidades locales usuarias del sistema, posiblemente hasta tiempos coloniales tardíos e incluso republicanos. Es, probablemente, necesario introducir aquí una nota. La discusión en torno a la continuidad y vigencia del sistema de arte rupestre en los Andes está abierta. Como veremos más adelante, en el Corregimiento de Atacama, hay varios registros que documentan el uso de sitios rupestres e inscripciones a lo largo del siglo XIX. En distintos espacios del centro sur andino existen algunos sitios de arte rupestre que siguen funcionando hasta la actualidad como parte de un sistema ritual (Arenas, Lima, Tocornal y Alvarado, 2015). Respecto a los despliegues visuales que se pueden identificar, contemporáneamente, y que remiten a la práctica de inscribir significantes visuales en muros y espacios rituales, los hemos podido identificar en los santuarios de Copacabana (Bolivia) y Quyllurit’i (Perú), amén de otros contextos (ver la reciente discusión de Arenas y Odone, 2016). 
Volviendo a nuestra revisión; en resumen, en esta cuenca, la más extensa, hemos identificado un total de 10 sitios, con un total de 19 registros. Si bien hay más sitios que en las otras cuencas, se trata más bien de casos aislados, y con una única salvedad (Oscu$\mathrm{ma})$, en convivencia con los registros prehispánicos más abundantes. Es decir, una densidad baja de registros; lo que podría estar relacionado con las formas de ocupación del espacio, con las prácticas de vida de las comunidades locales asentadas allí o con los mayores controles ejercidos por las autoridades coloniales, civiles y eclesiásticas. Un segundo aspecto resalta de los motivos coloniales que hemos registrado. En un posible ordenamiento cronológico (Figura 7), ellos tienden a concentrarse en registros que podemos asociar a los momentos iniciales de la invasión europea y de la evangelización en la zona (sensu Martínez C. y Arenas, 2015).

\section{Cuenca de Camiña}

En lo que se refiere a esta cuenca, podemos observar tres sitios con representaciones rupestres coloniales. Es significativo que, siendo una cuenca con una superficie de menos de la mitad de la cuenca de la pampa del Tamarugal, agrupa 31 registros en su interior.

En esta cuenca nos encontramos con los sitios Calatambo, Chillaiza I y Chillaiza II, este último muy significativo dado que posee la mayor concentración del total de registros de la cuenca. Un elemento que es importante mencionar es el hecho de que estos tres sitios se encuentran relativamente próximos entre sí, no distando más de un kilómetro entre Chillaiza I y II y no más de 20 kilómetros de distancia entre Calatambo y los mencionados.

Si bien en las páginas siguientes discutiremos comparativamente el emplazamiento de los sitios, no parece relevante que estos tres que describiremos ahora posean un patrón común desde el punto de vista de su ubicación en el paisaje, dado que todos ellos tienen una muy baja visibilidad exterior y alta dificultad para el acceso. Esto nos hace pensar que en la cuenca de Camiña los procesos de inscripción de significantes coloniales operaron de forma discreta, en espacios restringidos, de modos diferentes

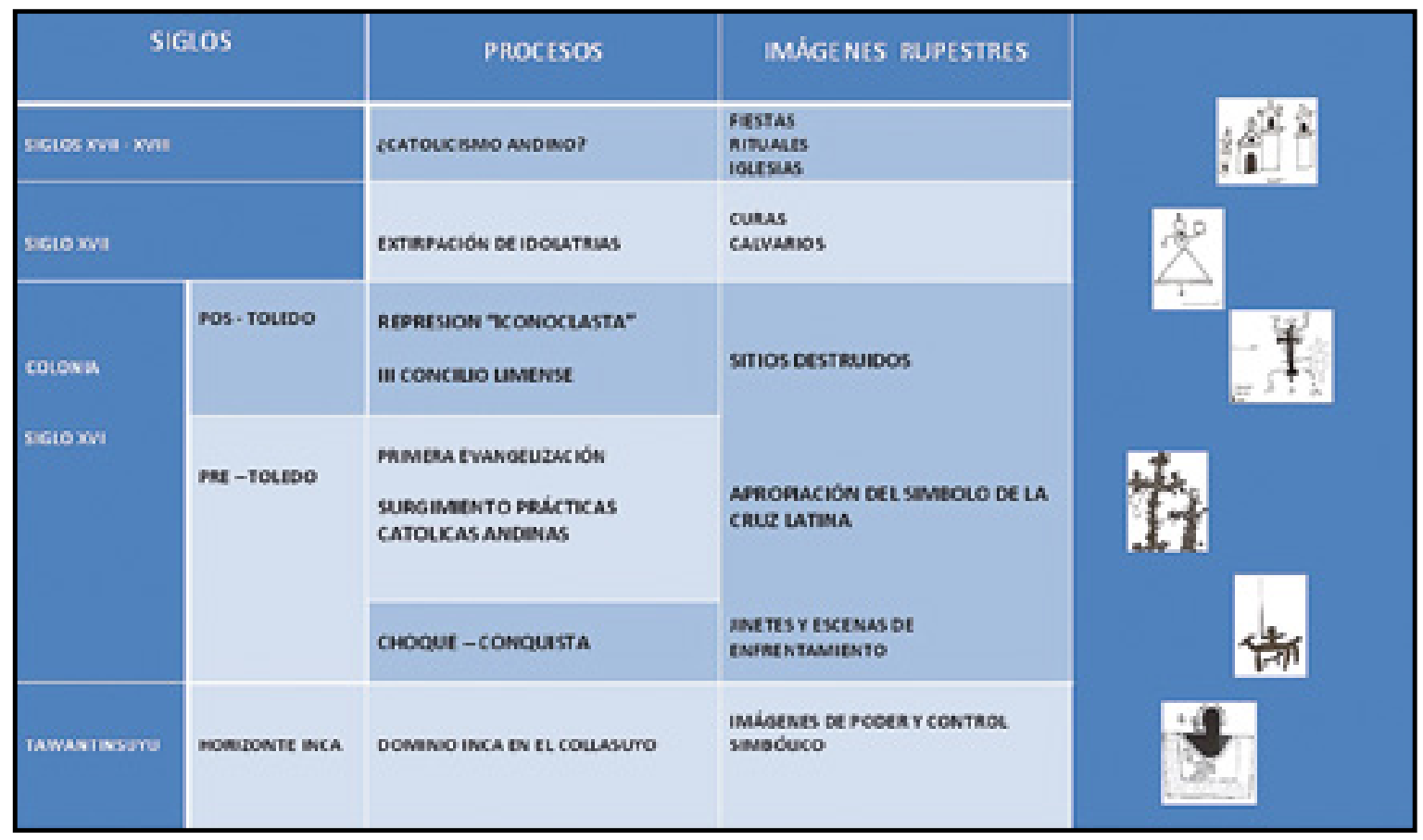

Figura 7. Propuesta de una cronología relativa del arte rupestre colonial en los Andes del sur (Según Martínez y Arenas 2015: 318). 
a lo que acabamos de ver en la cuenca de pampa del Tamarugal, más asociados a caminos y rutas de tránsito.

Nos llama la atención el caso de Chillaiza I y su relación con Chillaiza II. Teniendo ambos un patrón similar desde el punto de vista de su emplazamiento en el espacio, el primero posee solo cruces latinas que marcan la entrada al sitio. Las cruces latinas, como único significante colonial del sitio, contrastan con Chillaiza II, que posee una importante diversidad de motivos.

Chillaiza II es un repositorio de grabados prehispánicos que posee una diversidad de motivos: embarcaciones de diferente tipo, cruces sobre significantes geométricos y antropomorfos prehispánicos, representación de personajes coloniales con sombreros de copa con cruces y sin cruces, y también algunas representaciones asociadas a pinturas murales y pórticos de iglesias. Aquí se puede observar cómo algunos significantes coloniales se integraron al sistema en un movimiento armónico, solidario, sin un conflicto aparente, sin superposición o destrucción de los motivos precedentes. En algunos casos parecen resignificarse incluso algunos motivos antropomorfos esquemáticos frontales que portan una suerte de túnica cuadrangular. Sobre las extremidades superiores de estos personajes, tanto alzadas como caídas, se inscribieron o integraron cruces latinas, connotación que adquiere la representación de personajes asociados al sacerdocio cristiano, independientemente de si este corresponde a una apropiación del culto (sensu Martínez C. y Arenas 2015), o bien a una construcción de la alteridad. Del mismo modo se identifican cruces vestidas, similares a estandartes, como también significantes asociados a pinturas murales de iglesias (Figuras $8 \mathrm{a}$ y b).

Lo que hemos denominado anteriormente como la conservación o continuidad de significantes de origen prehispánico, en el presente colonial de las poblaciones tarapaqueñas se manifiesta en este sitio a través de la adición de una cruz latina a un círculo, constituyendo un nuevo significante que conjuga dos momentos históricos de la inscripción rupestre en este espacio.
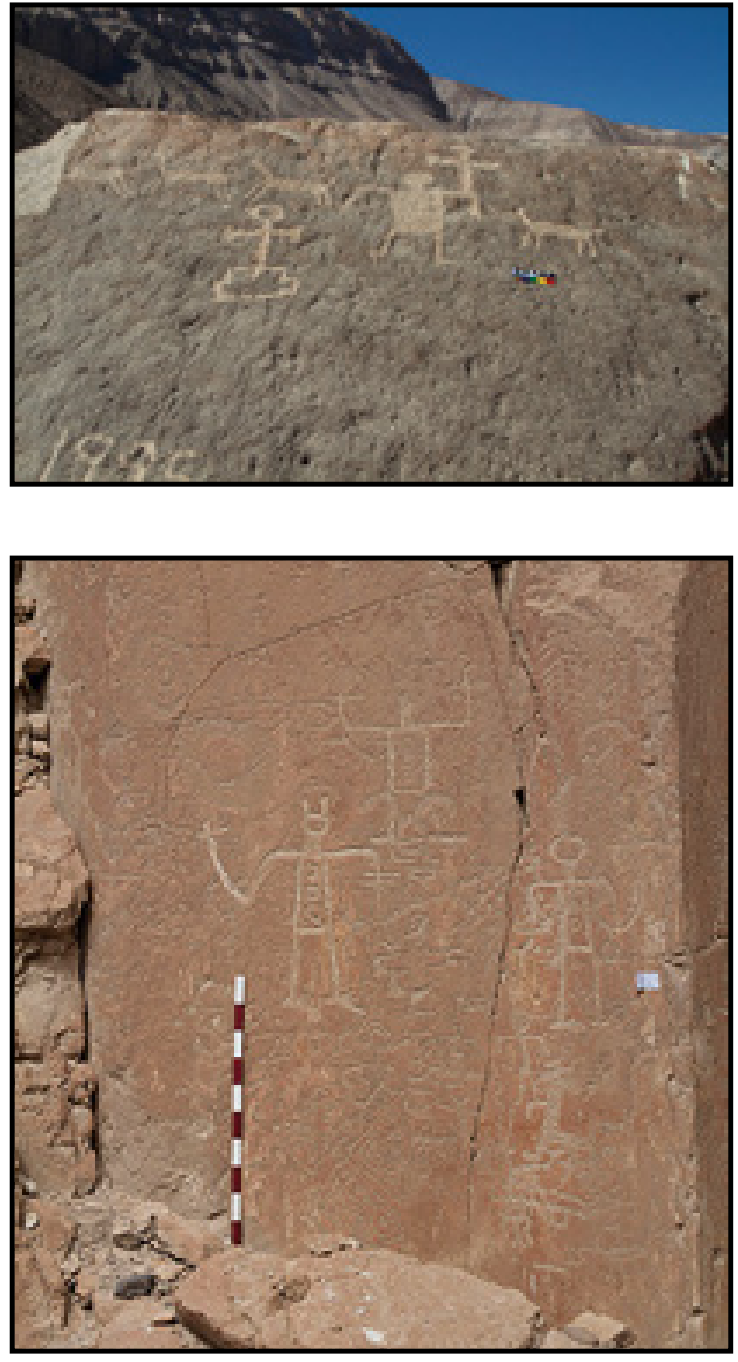

Figura 8 a y b. Antropomorfos portando cruces cristianas, posible resignificación de significantes antropomorfos andinos en el sitio de Chillaiza II, cuenca de Camiña.

Cruces con bases circulares se han identificado en otros sitios coloniales de los Andes del sur y, dicho sea de paso, una de las características del despliegue de algunas cruces latinas del sistema es su conjugación con significantes abstractos en la base, especialmente círculos. En estos casos se estaría expresando un nuevo orden significante que exhibe la interacción entre el pasado prehispánico y el presente colonial, produciendo una solución visual de nuevo orden.

En el mismo sitio de Chillaiza II podemos observar la incorporación de antropomorfos con sombreros 


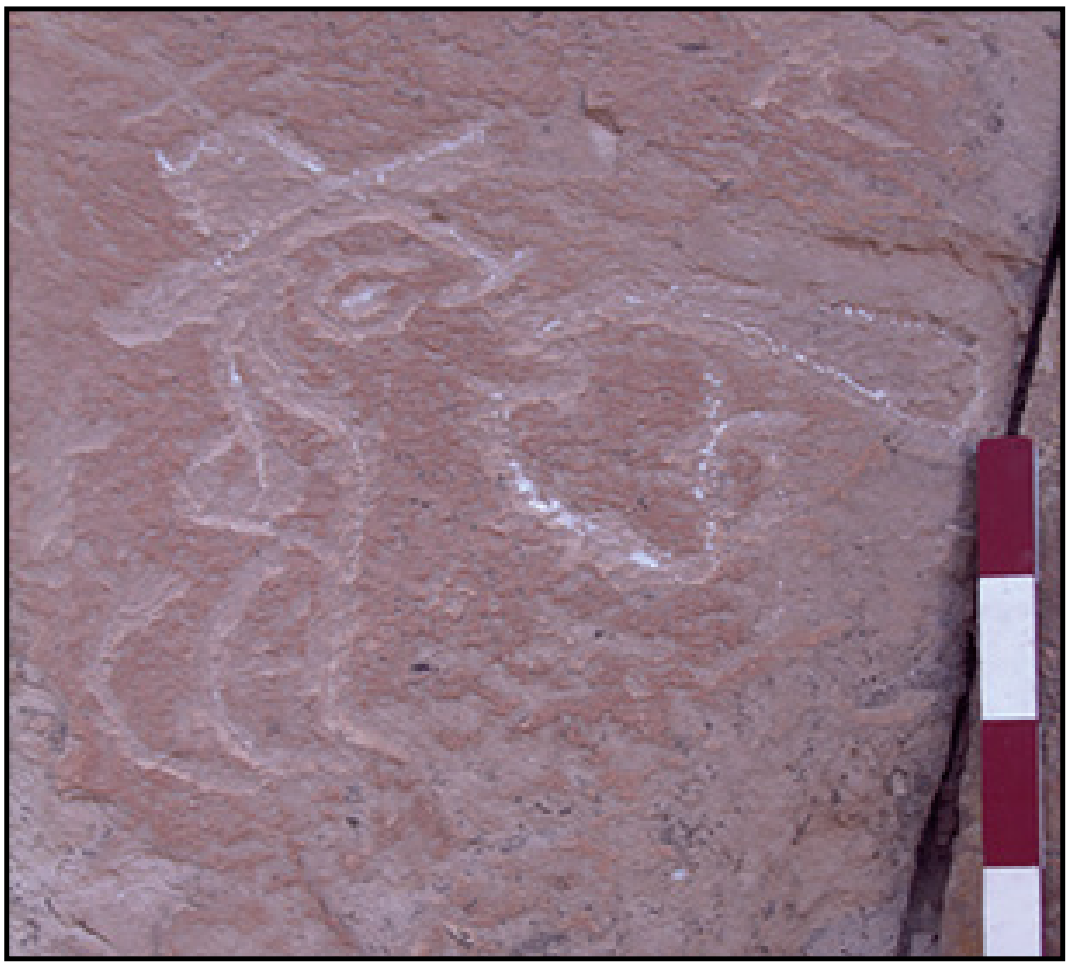

Figura 9. Personaje con sombrero alón significando las rebeliones indígenas andinas durante la segunda mitad del siglo XVII.

de copa y ala ancha, lo que podría estar representando la incorporación de un nuevo personaje en la estructura social local, el "mandoncillo". ${ }^{4}$ También nos encontramos con un significante que, proponemos, estaría representando acontecimientos asociados a las rebeliones indígenas del siglo XVIII (Figura 9); se trata de un antropomorfo portando una cruz cristiana en la parte superior frontal del sombrero. El personaje parece estar tocando una trompeta o pututu. Sugerentemente, durante las rebeliones tupacamaristas se ordenaba a los combatientes que portaran una cruz visible en el sombrero como señal de ser buenos cristianos. Tal como lo han planteado algunos autores, es posible que los rebeldes portaran cruces en sus vestimentas y sombreros. Micaela Bastidas, en 1780, habría instruido que portaran cruces como señal de ser buenos cristianos (Valcárcel, 1947, p. 141; Walker, 2014, p. 43). Túpac Amaru

4 La figura del mandoncillo y de autoridades indígenas coloniales está representada en diversas láminas de Guaman Poma (1616, fs. 751, 753, por ejemplo), caracterizados por utilizar sombreros de ala ancha. mismo es descrito colonialmente portando sombrero de copa y alón, amén de otros atributos (Gallardo et al., 1990). Y el pututu fue un arma usada por los rebeldes. Otros de los significantes que se pueden identificar en este sitio son embarcaciones, posibles carabelas o veleros cuyos detalles son diferentes: una posee símbolos cristianos, mientras que la otra, indicadores visuales asociados a lo bélico, como el detalle de los cañones (Figuras 10a y b).

Por último, en el sitio de Calatambo, que por su disposición también lo definimos como un espacio discreto, se puede observar un grabado de escritura alfabética y numérica que reza: "año 1800 Ceverino" (Figura 11). El texto se encuentra flanqueado por ambos lados por una cruz cristiana. La del lado izquierdo presenta una base triangular, mientras que la del lado derecho se proyecta como un gancho.

En resumen, se trata de una cuenca de tamaño menor que la anterior, con menos sitios, pero estos muestran una fuerte actividad, ya que en todos ellos hay más registros que en los sitios de la pampa del 

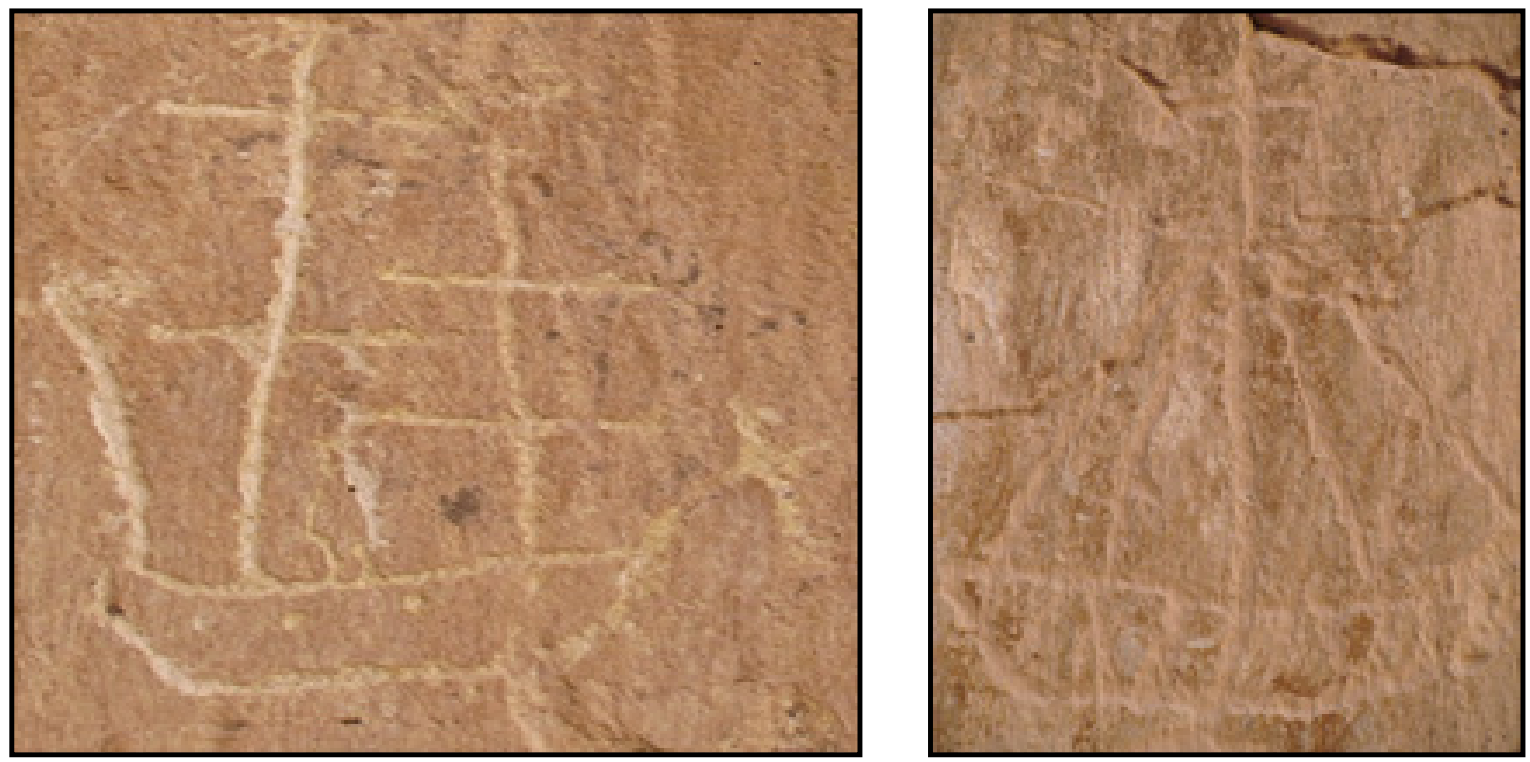

Figura 10 a y b. Carabelas coloniales en el sitio de Chillaiza II, cuenca de Camiña. Se observan detalles diferenciados, una porta significantes cristianos (cruces) y otras, significantes bélicos (cañones).

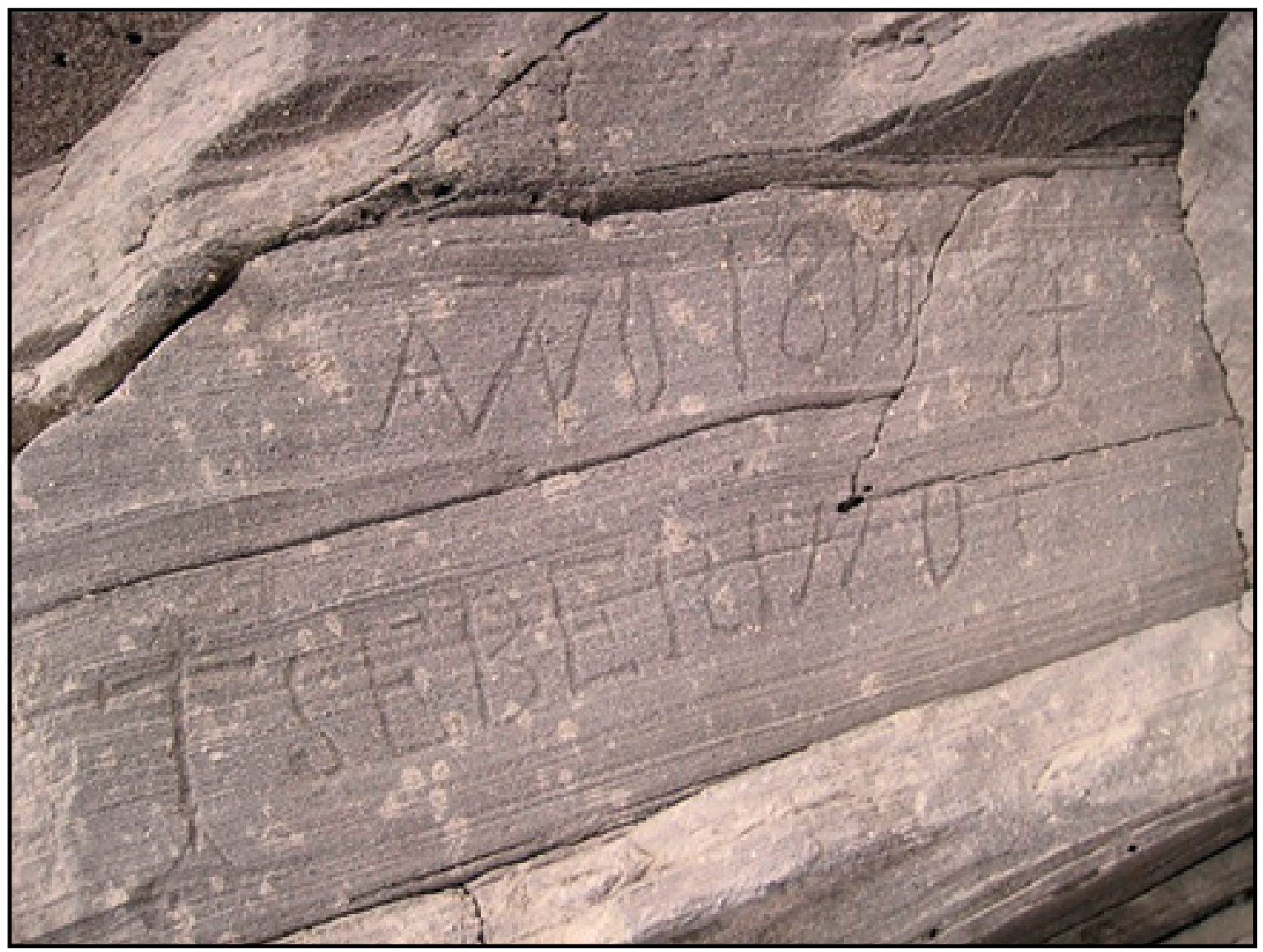

Figura 11. Inscripción ortográfica colonial tardía en el sitio de Calatambo, cuenca de Camiña. 
Tamarugal. El sitio Chillaiza II destaca por exhibir, él solo, 21 registros de una muy amplia gama de significantes y temas visuales. Un segundo elemento asoma al observar la variedad de registros: ellos cubren prácticamente todo el período colonial, de acuerdo a la propuesta de cronología presentada anteriormente, destacando aquí aquellos registros del siglo XVIII e inicios del XIX. Queda abierta, aún, la cuestión de la gran densidad y variedad de significantes coloniales y de su relación con otros, precolombinos, en el sitio Chillaiza II. ¿Ocurrieron allí procesos simbólicos, rituales o políticos particulares? Esperamos que futuras investigaciones en archivos y documentos coloniales nos aporten datos para encontrar algunas respuestas.

\section{Cuenca de Camarones}

Respecto de la cuenca de Camarones, podemos observar que esta agrupa cuatro sitios con representaciones coloniales. Es relativamente más extensa que la cuenca de Camiña y muchísimo más pequeña en superficie que la cuenca pampa del Tamarugal. En ella se han identificado los sitios de Suca, Angostura de Chiza, ubicados ambos en la subcuenca quebrada de Chiza; y hacia el norte, nos encontramos con los sitios Huancarane y Pampanune, ubicados entre estero Veco, río Caritaya y quebrada de Chiza.

En lo que se refiere a Suca, se trata de un sitio muy extenso con más de 14 sectores en su interior, en el cual se puede apreciar una gran cantidad de significantes rupestres prehispánicos (Sepúlveda, Romero, Guevara, Álvaro y Briones, 2005) y exhibe un número importante de registros rupestres coloniales, representando prácticamente la mitad del total de registros identificados en lo que fue el Corregimiento de Tarapacá. Este sitio expone un importante repertorio significante, incorporando en su interior la representación de jinetes, cruces latinas, inscripción de fechas y cruces sobre significantes geométricos prehispánicos.

Hacia el norte se encuentra el sitio Angostura de Chiza, el cual posee un total de ocho registros: escritura de fechas, inscripción de cruces y representación de un jinete con un arma en su extremidad (Figura 12). ¿Personajes históricos o categorías? ¿El conquistador tal, o una representación de la violencia europea,

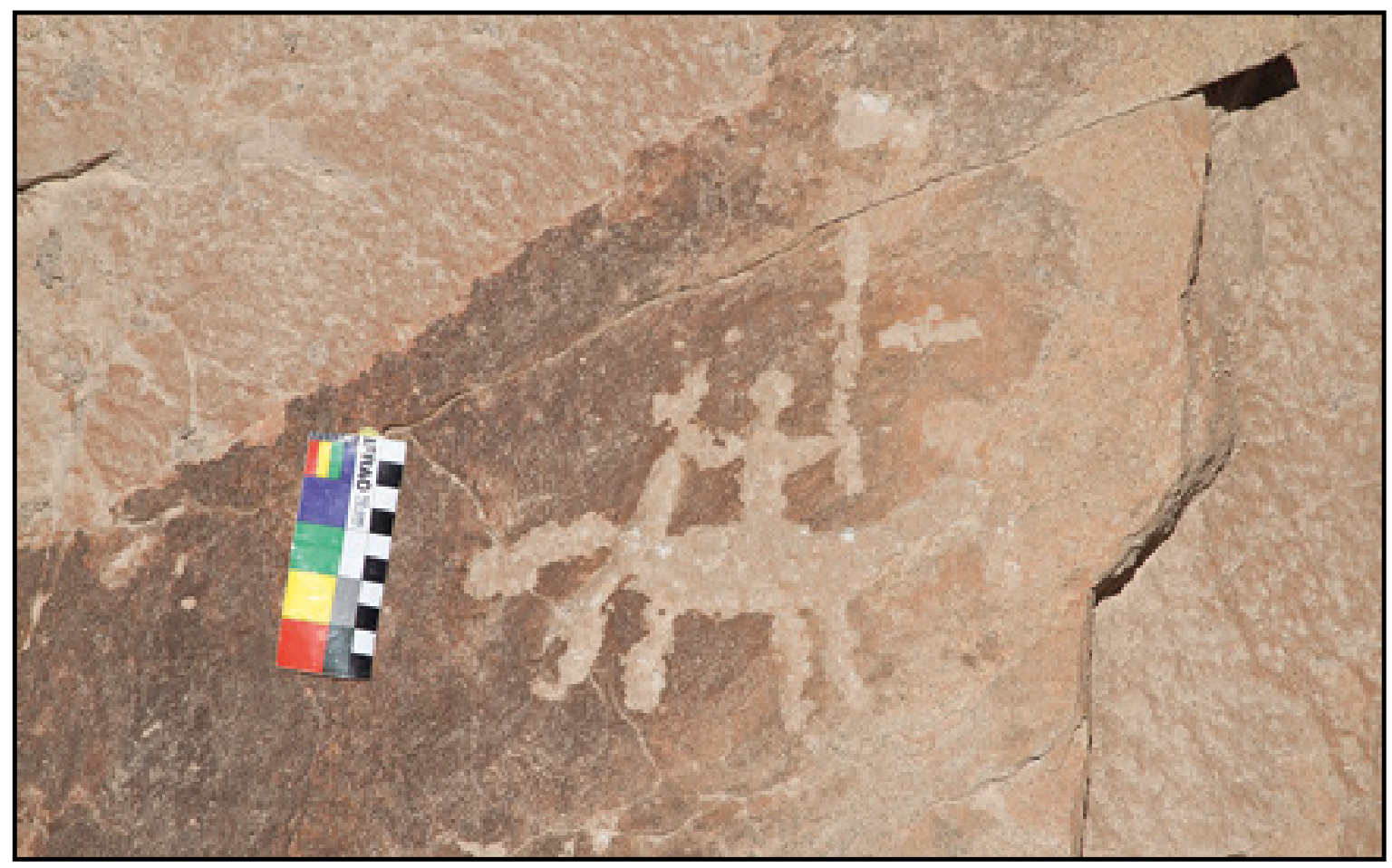

Figura 12. Bloque con significantes ecuestres en el sitio Angostura de Chiza, cuenca de Camarones. 


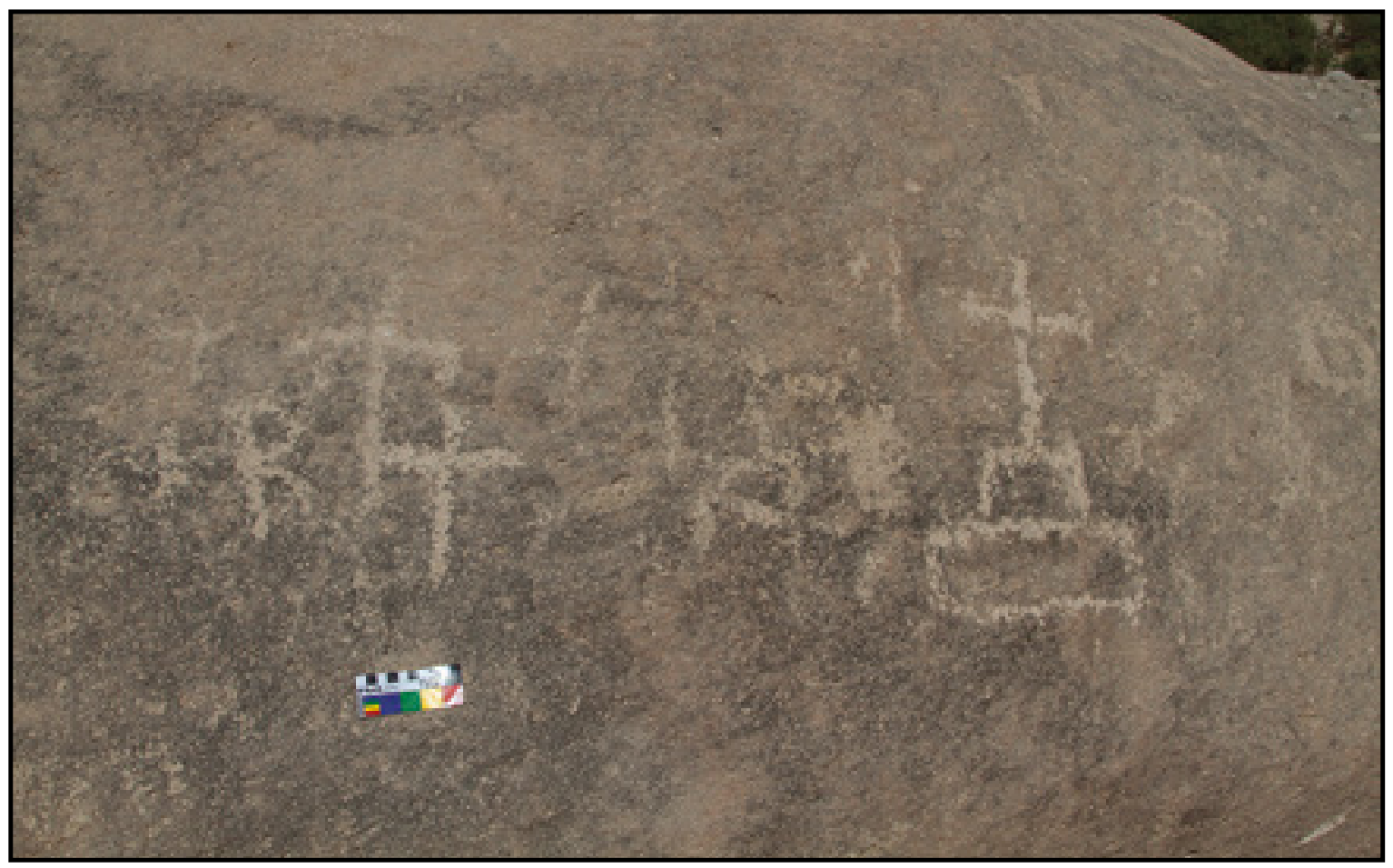

Figura 13. Bloque con significantes cristianos (cruces latinas y de calvario) en el sitio de Huancarane, cuenca de Tarapacá.

aplicada sobre los andinos? Esta imagen parece dar cuenta de que aquí también encontramos evidencia de una práctica comunicacional muy común y generalizada en el arte rupestre colonial de representar personajes, ya fueran históricos o categoriales, que daban cuenta de posibles acontecimientos, del desarrollo de procesos sociopolíticos o de la emergencia de nuevos actores sociales. No se trata de una situación aislada. Se ha señalado la presencia de motivos ecuestres similares en Tiquina (en la cuenca pampa del Tamarugal) y en Huancarane (cuenca de Camarones).

Continuando hacia el norte nos encontramos con el sitio de Huancarane (Niemeyer y Schiappacasse, 1981; González, 2014), con el doble de registros que el sitio anterior. En él se pueden observar diversos motivos, como cruces latinas y de calvario, también se han identificado motivos ecuestres ubicados en la periferia de este importante repositorio rupestre, sin romper el sentido de este espacio sacro de origen prehispánico. En uno de los bloques se observan cruces latinas y en un extremo una cruz calvario de base escalonada (Figura 13).
En el mismo sitio otras cruces de calvario conviven yuxtapuestas a significantes andinos sin entrar en conflicto aparente. También se observa la existencia de un bloque en el cual cruces latinas se yuxtaponen a una escena de camélidos prehispánicos (Niemeyer y Schiappacasse, 1981; González, 2014).

Como muchos de los otros espacios observados, este sitio siguió funcionando durante el período colonial con su propia lógica, operando bajo el principio de apropiación selectiva (la incorporación de solo determinados significantes de la vida colonial y religiosa); sin descartar la realización de algunas acciones de censura, relacionadas con la imposición del ícono cristiano de la cruz sobre significantes andinos prehispánicos, lo que evidencia las tensiones vividas por esas comunidades y sus espacios religiosos y colectivos.

Esto no solo confirma la continuidad del funcionamiento de estos espacios sacralizados avanzado el proceso colonial y da cuenta de la persistencia de la cultura propia (sensu Arenas y Odone, 2015), sino que nos proporciona luces acerca de las prácticas que tenían lugar allí. 
En este sentido, proponemos la presencia de lógicas diferenciadas de inscripción en este espacio: primero, una tendencia a construir un espacio discreto de inscripción andino/católico; segundo, la coexistencia entre los elementos prehispánicos y coloniales y tercero, la invisibilización de motivos, esto es, visibles únicamente si el observador está en ese espacio acotado. Esto nos hace pensar en una ocupación multipropósito del sitio, la cual podría estar a la vez señalando la continuidad durante diferentes momentos de la Colonia.

De Huancarane al este nos encontramos con Pampanune, con dos registros de significantes coloniales. Se puede observar escritura de nombres propios, cargos y fechas.

Llama la atención la densidad representacional en esta cuenca. Solo en el sitio de Suca se cuentan 72 registros; ello sugiere un uso reiterativo de esos lugares, abriendo preguntas sobre las dinámicas sociales y religiosas desarrolladas por las poblaciones locales y por qué ellas parecieran ser diferentes a lo que vimos anteriormente, sobre todo en la cuenca pampa del Tamarugal. Es, igualmente, el sector con un mayor número de registros alfabéticos y calendárico occidental, uno de ellos con la fecha 1770 (Pampanune).

\section{Corregimiento de Atacama}

Este corregimiento se ubica inmediatamente al sur del de Tarapacá, aunque administrativamente estaba vinculado a la Audiencia de Charcas y no a la de Lima, como el primero. Estaba organizado en dos doctrinas o curatos, la de Atacama la Baja, con sede en Chiuchiu (donde residía el corregidor en el siglo $\mathrm{XVI}$ ), que se extendía desde el borde puneño cercano a la actual localidad de Ollagüe hasta la costa, donde Cobija era el puerto. La otra doctrina, de Atacama la Alta, en cambio, sin salida al mar, abarcaba toda la actual cuenca del salar de Atacama y las tierras altas de parte de la actual puna atacameńa (hoy en Argentina).

Sus poblaciones coloniales estaban básicamente concentradas en las cuencas hidrográficas del río Loa y del salar de Atacama. En Atacama la Baja, la mayor cantidad de poblados se encuentra en la sub- cuenca del río Salado, donde estaban las localidades de Ayquina, Caspana y Turi-Paniri. Y en el río Loa medio se ubicaban los centros de Chiu Chiu y Calama, un importante oasis forrajero para la época. En cuanto a Atacama la Alta, sus poblaciones se concentraban regularmente en los bordes del salar de Atacama, con una densidad de poblamiento mayor en el borde norte del mismo, con su centro en San Pedro de Atacama y los ayllus cercanos.

En este corregimiento no conocemos registros coloniales localizados en la pampa y sectores costeros. Sí conocemos registros en ambas cuencas y en la puna, donde había algunas pequeñas localidades dispersas, en las cercanías del poblado de Susques (Rivet, 2013).

\section{Cuenca del río Loa}

En la cuenca del Loa no poseemos hasta el momento un análisis estadístico del número de registros y conjuntos significantes coloniales identificados para cada sitio. Para algunos de los sitios asociados al curso superior del mismo río contamos con fuentes secundarias y algunas observaciones de campo realizadas por dos de los autores en distintos momentos. Para el sector de Ayquina (en la subcuenca del río Salado), nos basamos en los estudios realizados por Gallardo et al. (1990). A pesar de esta limitación, se puede realizar una aproximación adecuada al emplazamiento de los sitios y sus contenidos significantes.

En el curso superior del río Loa, en el sector de la Rinconada de Santa Bárbara, importante cruce de caminos desde tiempos prehispánicos, se encuentra el Alero de Santa Bárbara. Al lado de un sendero tropero ${ }^{5}$ que pasa por su cercanía, se encuentran grabados en un paredón rocoso un conjunto de 17 camélidos esquemáticos, en donde se observan al menos cinco camélidos con la cola larga, otros cuatro se configuran como escenas de monta o motivos ecuestres, en donde tres de ellos presentan rasgos de "montura" y un cuarto porta en el lomo un personaje con túnica cuadrada decorada con una "X" y sombrero alón. Otros tres antropomorfos pedestres

5 Por camino tropero estamos entendiendo aquellas rutas usadas por las caravanas de llamas prehispánicas y, colonialmente, por los arrieros y las recuas de mulas, o "tropa" de mulas, como se las llamaba en la época. 
muestran los mismos atributos de una túnica cuadrada y sombrero alón; dos de ellos parecen portar un bastón (Berenguer, 1999, p. 47). Además de la identificación de estos personajes como posibles mandoncillos, ya comentados para el sitio de Chillaiza II, la configuración del motivo ecuestre a partir de camélidos esquemáticos es diagnóstica respecto del proceso de transformación visual de los camélidos en caballos, tratándose de una construcción muy temprana o inicial de este motivo colonial. En este sitio, el principal atributo de los cuadrúpedos como rasgo diferenciador entre camélido y caballo es la cola larga (véanse Figuras 12 y 5).

En el mismo sector de la Rinconada de Santa Bárbara, sobre una pared o planchón rocoso se observa un velero, a cierta distancia de una cruz calvario de base triangular (Berenguer, 1999, p. 45). Hay, asimismo, una serie de iniciales, nombres y fechas, entre otros significantes, que Berenguer, Aldunate, Castro, Sinclaire y Cornejo (1985, pp. 103-104) asocian a la fase La Costa, ya en período republicano, considerando las fechas grabadas en ese panel $(1860,1865$, 1880 y 1885 DC). En ninguna de las dos fuentes consultadas se menciona la cruz calvario de base triangular que está grabada cerca del velero.

En el flanco oeste del cañón del Loa, frente a la posta de Santa Bárbara, sobre el talud en una pared de roca vertical, se ubican al menos dos conjuntos de arte rupestre prehispánico que pueden corresponder al período Tardío. El grupo más prominente corresponde a un conjunto en técnica de pintura roja lineal. Una escena central desarrolla dos motivos antropomorfos "enfrentados" y separados por unas líneas paralelas en zigzag que alcanzan el tamaño de los antropomorfos. Sobre este panel, interviniendo parte de las pinturas, se instalaron tres cruces calvario de base triangular con técnica de grabado. La más grande presenta un desarrollo de contorno lineal con decoración interior. Otras dos cruces calvario son de menor tamaño, presentan una base rectangular grabadas con tratamiento de superficie areal (sensu Gallardo, 2005 y 2009) (Figuras 14a, b y c).

Unos metros más al sur, también sobre el talud y en la pared de roca se grabaron tres motivos zoomorfos. Dos corresponden a siluetas o perfiles de "monos" grabados con el procedimiento de contorno lineal y tratamiento de superficie areal (Gallardo, 2005). Este motivo es muy parecido a los observados en la cerámica del período Tardío del valle de Azapa. También se observa un cóndor en posición frontal y cabeza de perfil con desarrollo lineal de las extremidades y desarrollo areal en el cuerpo y la cabeza, típico de los repositorios rupestres de Tarapacá. Sobre este último motivo se grabó una cruz calvario de gran tamaño y desarrollo lineal con decoración interior, similar a la del panel anterior. A la derecha de estos motivos se puede ver una cruz calvario de menor tamaño, con base triangular y tratamiento de superficie areal.

La ubicación de estos paneles frente a lo que fue una posta en el camino carretero que pasa por Santa Bárbara, un espacio de circulación colonial, invita a pensar que los paneles prehispánicos fueron identificados y reprimidos tanto por su visibilidad pública como por la posibilidad de que los mismos continuaran funcionando a pesar de la circulación cercana de funcionarios, autoridades y personajes vinculados al poder español, lo que habría motivado una acción de extirpación de idolatrías. Sería interesante hacer una reflexión sobre estos motivos iconoclastas y la presencia del extirpador de idolatrías Francisco de Otal en la región a mediados del siglo XVII (Castro, 2009; Hidalgo, 2011, 2014).

En un sector más alejado del cruce de Santa Bárbara hemos tenido la oportunidad de observar un gran panel con varios equinos grabados en formato grande. Desde el punto de vista de su composición, son similares a algunos de los équidos montados de contorno lineal descritos en Ayquina (Gallardo et al., 1990, fig. 4). Lo singular es que en este panel del Loa los caballos son de gran tamaño, no se encuentran montados y presentan el cuerpo "moteado" al modo de algunos felinos grabados diagnosticados como prehispánicos.

Un poco más al norte de este sitio, en la quebrada Quinchamale, en un bloque aflorante se observan grabados dos jinetes a caballo que por sus atributos podrían ser más tardíos (siglos XVII-XVIII). En una posición inferior, aparece una serie lineal de signos alfabéticos que podrían estar representando marcas de arrieros (Berenguer, 1999, p. 47). 

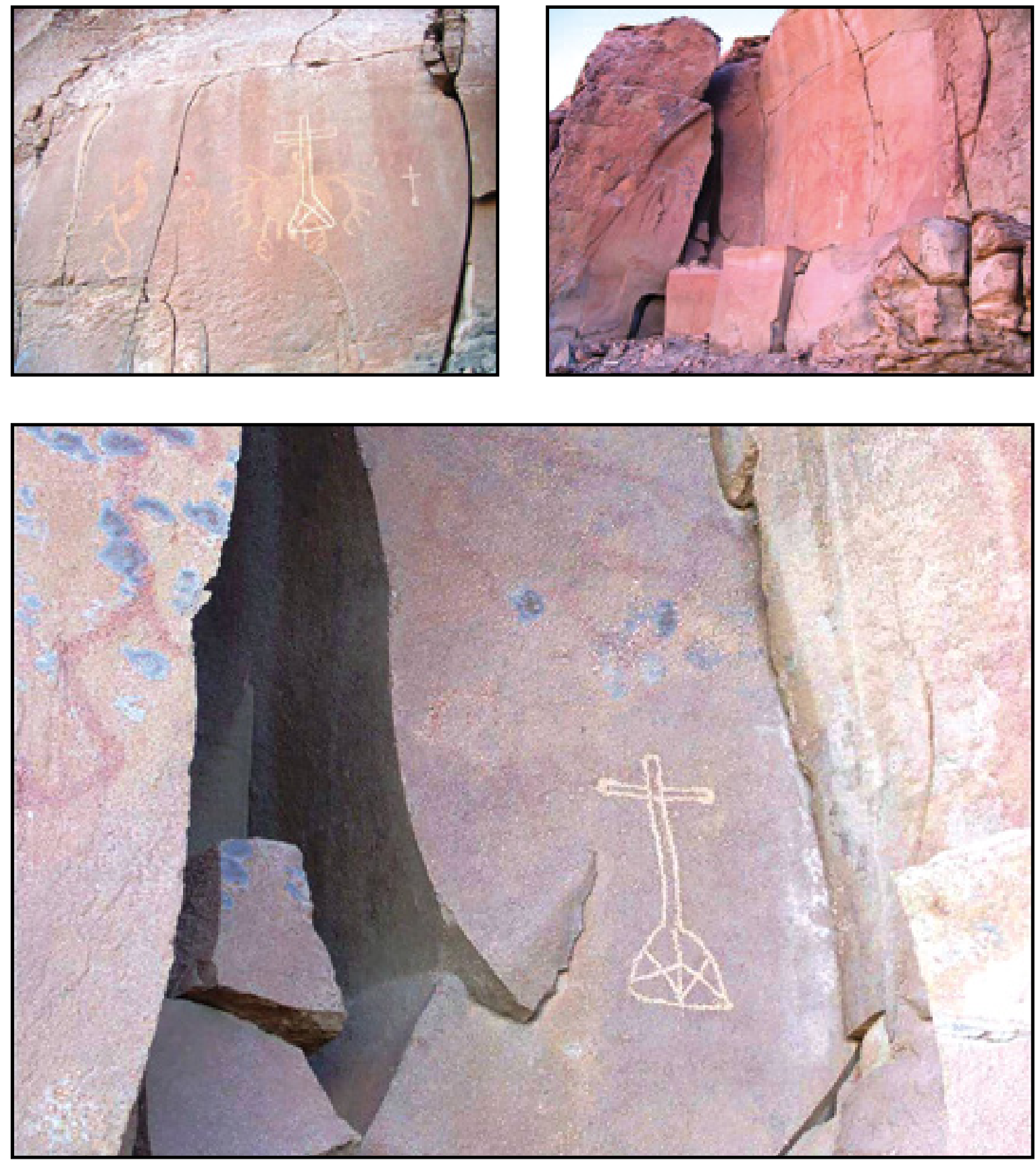

Figura 14 a, b y c. Cruces calvarios sobre pinturas rupestres del período Tardío en las paredes del cañón de Santa Bárbara como signos de la extirpación de idolatrías en la cuenca del río Loa, sector Alto Loa.

Siguiendo hacia el norte se encuentra el sitio identificado como Alero Zurita. A un costado de la puerta de acceso del frontis pircado, en la superficie plana de una roca que sirve de marco a la puerta de acceso al alero, se observa una cruz latina con base triangular grabada con un surco profundo. El mismo motivo se repite al interior del alero en técnica de pintura en color negro. Su tamaño es más pequeño y se dispone en la parte superior de un panel con distintos motivos prehispánicos (Berenguer, 1999, p. 48). Un motivo antropomorfo esquemático que parece representar a una mujer con faldón o bien un 
traje de fiesta, se encuentra grabado en otro sector del alero.

Subcuenca río Salado. Desde un kilómetro aguas abajo del pueblo de Ayquina y en un tramo de unos $3 \mathrm{~km}$ se han registrado 57 paneles de arte rupestre, con presencia de grabados y pinturas. La temática de representación es principalmente prehispánica, pero también se han identificado significantes coloniales como el motivo ecuestre (Gallardo et al., 1990, p. 29). La representación de la figura humana es escasa. Esta se encuentra asociada a camélidos y a escenas de monta en cuadrúpedos, estas últimas que emplean la técnica de grabado y se concentran fundamentalmente en la pared norte de la quebrada. Siguiendo a Gallardo (2005, pp. 29-30), se observan motivos ecuestres, con "posesión de objetos alargados en una de sus manos; extensión del brazo libre hacia el cuello del animal, que en ocasiones sugiere la presencia de riendas y líneas adicionales en la cabeza que recuerdan sombreros de ala ancha. Con respecto a la cabalgadura, el animal es representado con dos o cuatro patas, las que, en algunas figuras, muestran un engrosamiento en el sector de los cascos".

Así, en la cuenca de los ríos Loa y Salado, lo que observamos es una alta concentración de los sitios con significantes rupestres coloniales. En el sector alto del río Loa se han identificado al menos cinco sitios, todos muy cercanos, en el sector de Rinconada de Santa Bárbara; otro sitio en la quebrada Quinchamale y, finalmente, uno más en Alero Zurita. Cuantitativamente, pareciera que la mayor cantidad de registros se concentra en el sector de Santa Bárbara, de gran circulación y visibilidad para aquellos viajeros y arrieros coloniales que se desplazaban desde la costa del Pacífico o desde los centros poblados de Chiu Chiu y Calama hacia las tierras altas que conducían a Lípez y, de ahí, a Potosí y Charcas. Los sitios Quebrada Quinchamale y Alero Zurita son excéntricos respecto de esas rutas y están más conectados a sectores de pastoreo y circulación de caravanas de camélidos, configurándose lo que aquí hemos denominado "espacios discretos". En el río Salado, sorprendentemente para nosotros dada la mayor cantidad de poblados, los registros se concentran en un único espacio próximo al poblado de Ayquina. Allí la densidad de registros es sorprenden- te, así como la interacción armónica entre las imágenes prehispánicas y las coloniales.

\section{Cuenca del salar de Atacama}

En la cuenca del salar de Atacama las informaciones respecto al arte rupestre colonial a partir de fuentes secundarias son mucho menos específicas que aquellas de las cuencas más septentrionales. Nuestros propios registros son, también, incipientes. Se tiene información relevante respecto al emplazamiento de algunos sitios que han sido reportados con un componente de significantes coloniales, aunque no podemos afirmar si, en la mayoría de los casos, estos adscriben estrictamente al período Colonial. Debemos a Lautaro Núñez (com. pers. a J. L. Martínez, 2016) noticias sobre los contenidos coloniales de varios de estos sitios; otros hemos podido visitarlos personalmente, lo que nos permite adelantar algunas reflexiones.

Sector Norte de la cuenca. Ubicado en el sector de pampa Viscachillas, en el territorio de la comunidad atacameña de Río Grande, al noreste de San Pedro de Atacama, se encuentra el sitio de Yerbas Buenas. Se reconocen dos afloramientos liparíticos conocidos como "catedrales" fuertemente afectados por la erosión. Presentan una importante concentración de motivos rupestres. Se les denomina Sector 1 y 2 . Tamblay señala: "la Estancia de Yerbas Buenas fue un asentamiento transitorio, de ocupación no permanente, al centro de una zona estratégica de paso regional, desde o hacia el oasis San Pedro de Atacama, siguiendo la ruta más corta próxima al agua, aprovechando vías orográficas naturales (Tamblay, 2004, p. 371). El citado autor ha estudiado con detalle el componente prehispánico de este sitio.

En dicho contexto, es posible observar algunos motivos coloniales y otros de data más reciente, especialmente en el Sector 2 (Figuras 15a y b). Estos motivos no fueron referenciados por Tamblay (2004). En el mencionado sector, en las paredes de rocas que se orientan hacia el sur se observa una serie de grabados que pueden corresponder a distintos momentos históricos. Lo interesante de constatar es la pervivencia de la práctica del grabado hasta prácticamente la actualidad, privilegiando la ocupación del soporte no intervenido anteriormente, denotando el 
principio de solidaridad diacrónica a nivel del espacio y no solo a nivel de un panel, como es posible observar en otros sitios. Las temáticas representadas corresponden a motivos de caballos, zorros, camélidos, antropomorfos con vestimentas, letras y mascariformes, entre otros. La mayoría de los motivos funciona por disposición, es decir, se representan aislados, sin configurar escenas o yuxtaposiciones significativas. En el Sector 1 de Yerbas Buenas logramos identificar la presencia de cruces cristianas en un solo panel en un bloque suelto, asociadas a un área de abrigos rocosos.
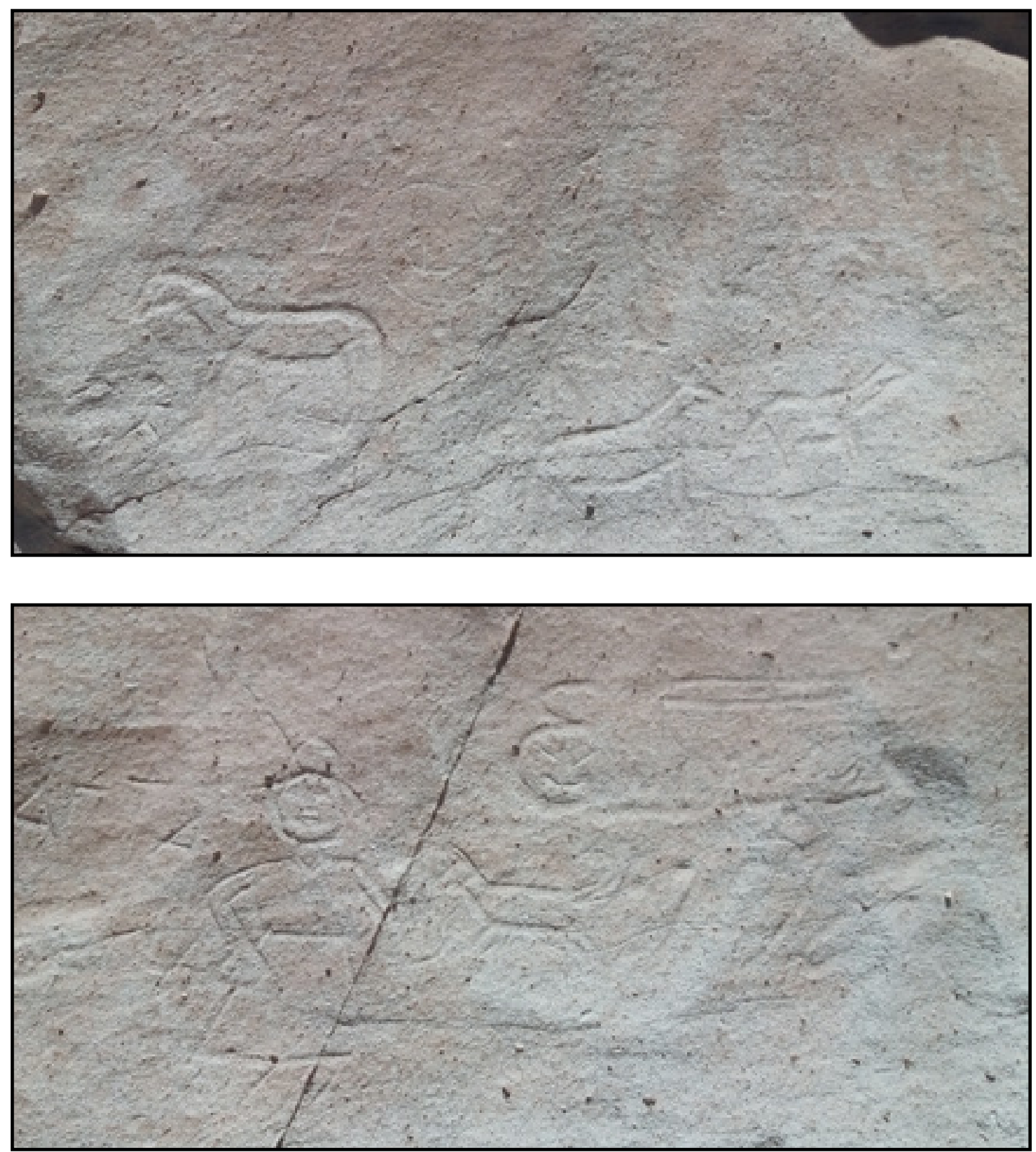

Figura 15 a y b. Grabados de caballo y camélidos contrapuestos y personaje con su perro y mascariforme en un friso rocoso del Sector 2 de Yerbas Buenas. 
Muy cerca del paso Barros Arana en la carretera Ch23, cordillera de Domeyko, se encuentra el sitio que hemos denominado Paso Barros Arana; está asociado a una antigua ruta que comunicaba los oasis de San Pedro de Atacama y el oasis de Calama. Se trata de una serie de refugios naturales con estructuras de pirca y corrales asociados. En uno de estos refugios es posible observar algunos motivos grabados correspondientes a los períodos Prehispánico, Colonial y otros más recientes. Llama la atención el grabado de un motivo antropomorfo de desarrollo esquemático lineal "apuntando" con un posible fusil, similar a los reportados por Hostnig (2004) para el arte rupestre de la provincia Espinar (Cusco).

En el sitio conocido como Río Salado o Chuschul, Niemeyer (1968) reproduce un motivo ecuestre "arreado" por un antropomorfo de pie, por medio de una posible soga. Este autor la interpreta como una escena festiva en donde se encontrarían interactuando "un muchacho y una llama". Discutiendo un sitio culturalmente cercano a Atacama, en la quebrada de Humahuaca en Jujuy, Hernández Llosas (2006) propuso que el significante de la soga podía ser interpretado como una señal de derrota, de violencia; lo que es coincidente con las representaciones de los vencidos andinos, tal como las dibuja Guaman Poma (1616, fs. 115, 434, 449). Ello podría sugerir otra lectura de este conjunto visual.

En otro panel también se reproduce una escena de monta, aunque Niemeyer interpreta al cuadrúpedo como un camélido. En este mismo panel aparecen inscritas al menos tres cruces que se podrían interpretar como cristianas, a las cuales el autor no hace referencia, pero que se integran al sistema rupestre en lo que hemos llamado más arriba, solidaridad diacrónica. Parece corresponder al sitio identificado como Salado-2 (Núñez, Cartajena, Loo, Ramos, Cruz y Cruz, 1997, p. 321), con presencia de murales rupestres y estructuras arquitectónicas. El arte rupestre es diagnosticado como de la fase Solor (900-1450 DC) y motivos históricos.

En este sector Núñez et al. (1997) han identificado también otros siete sitios en los que aparecen motivos significantes coloniales junto a registros rupestres de las fases Catarpe (1470-1535 DC) y Solor
(900-1450 DC). Los autores refieren, sin describir los motivos, que alguno de ellos corresponde a "fases históricas" (1997, pp. 21-323). Se trata de los sitios Purilactis 2, Purilactis 4, Purilactis 6, Los Arrieros 1, San Bartolo 3, Cuchabrache 1 y Quebrada Tambores. En el caso del sitio San Bartolo 3, también se advierten significantes atribuibles al período Inka. Un sitio que destaca en este conjunto es Purilactis 4, en el que solo se han identificado manifestaciones atribuibles al período Colonial o posterior.

En el sitio Quebrada Tambores, que pudimos recorrer gracias a la compañía de Lautaro Núnéz, se encuentran varios motivos coloniales, todos ellos en solidaridad diacrónica con las representaciones prehispánicas. Aquí se pueden identificar al menos dos figuras ecuestres y una cruz con base triangular (Figuras 16a y b).

Ambas figuras, montadas, lo hacen en realidad en una superposición de un antropomorfo sobre un camélido, un procedimiento que siguiendo a Gallardo et al. (1990) hemos ubicado cronológicamente en períodos tempranos de la invasión europea a los Andes, en el siglo XVI. Aunque bastante deteriorada, una de las figuras montadas parece estar enfrentada a un antropomorfo a pie, que sostendría un objeto alargado en una de sus manos (Figura 16c). Si nuestra interpretación es correcta, se trataría de una escena de enfrentamiento entre indígenas y españoles, también de amplia difusión en el área andina.

En Purilactis 2, donde se reconoce un mural asociado a una estructura rectangular y un corral con evidencia de reocupaciones, el arte rupestre se adscribe a la fase Catarpe y al período Colonial (Núnez et al., 1997, p. 321). Aquí se han identificado una cruz cristiana, un personaje con sombrero al parecer de tipo europeo e, incluso, un diseño que Lautaro Núnez (com. pers. a J. L. Martínez, 2016) identifica como posible baile de iglesia (Figuras $17 \mathrm{a} \mathrm{y} \mathrm{b).} \mathrm{De}$ acuerdo a este investigador, "[s]e trata de un baile ritual entre dos personajes. El de la izquierda tiene algo parecido a un turbante con emplumados (?). El otro no tiene sombrero, pero en su parte trasera parece representar una cola de ave (¿suri?). Los objetos que portan se ven abultados en sus extremos. A la derecha un diseño humano menor parece ejecutar 

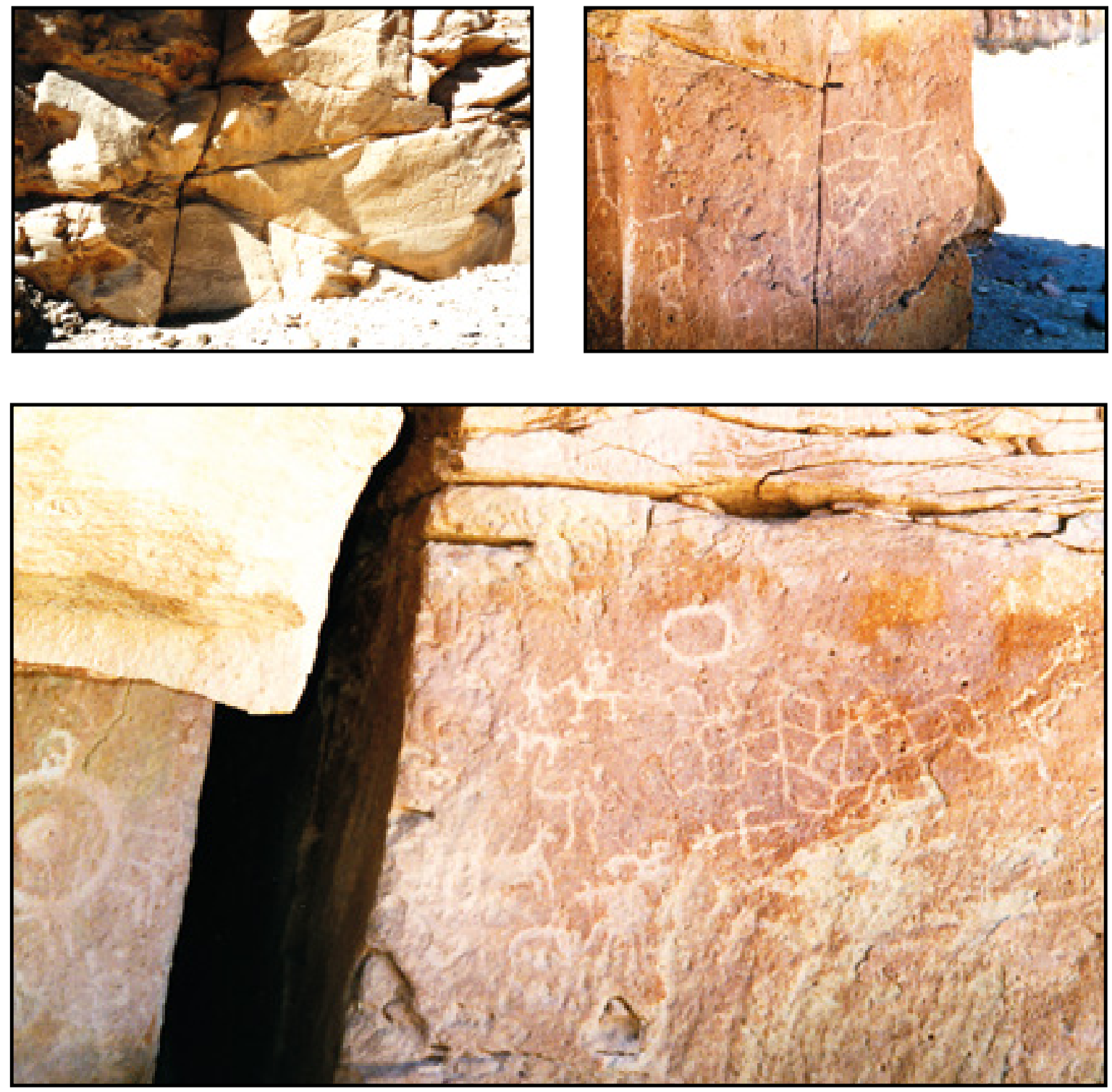

Figura 16 a, b y c. Cruces y antropomorfos montados en camélidos, en el sitio Quebrada Tambores.

un tambor o una caja chayera”. El personaje mayor porta en su espalda algo agregado que podría interpretarse como un par de alas.

Es sugerente la proposición de Núñez (2004, p. 39; y com. pers. a J. L. Martínez, 2016) respecto a que este conjunto significante estaría representando una danza con "bastones" presente también en una lámina de la Nueva Corónica y Buen Gobierno de Guaman Poma (1616, f. 783), en la que se muestra a los hijos de los principales que deben bailar dentro de la iglesia como parte de sus actividades de evangelización. Núñez propone varias similitudes: son dos andinos enfrentados que acogen en San Pedro de Atacama el sombrero "moro" con adornos emplumados. El sombrero cucurucho apegado a la espalda en Guaman Poma aún se usa en los bailes de San Pedro de Atacama. Los bastones que portan los bailarines son dos en el grabado rupestre, uno en la lámina de Guaman Poma, pero en ambos casos son abultados en el extremo. Es este mismo autor quien destaca la importancia de los bailes o taquis en los 

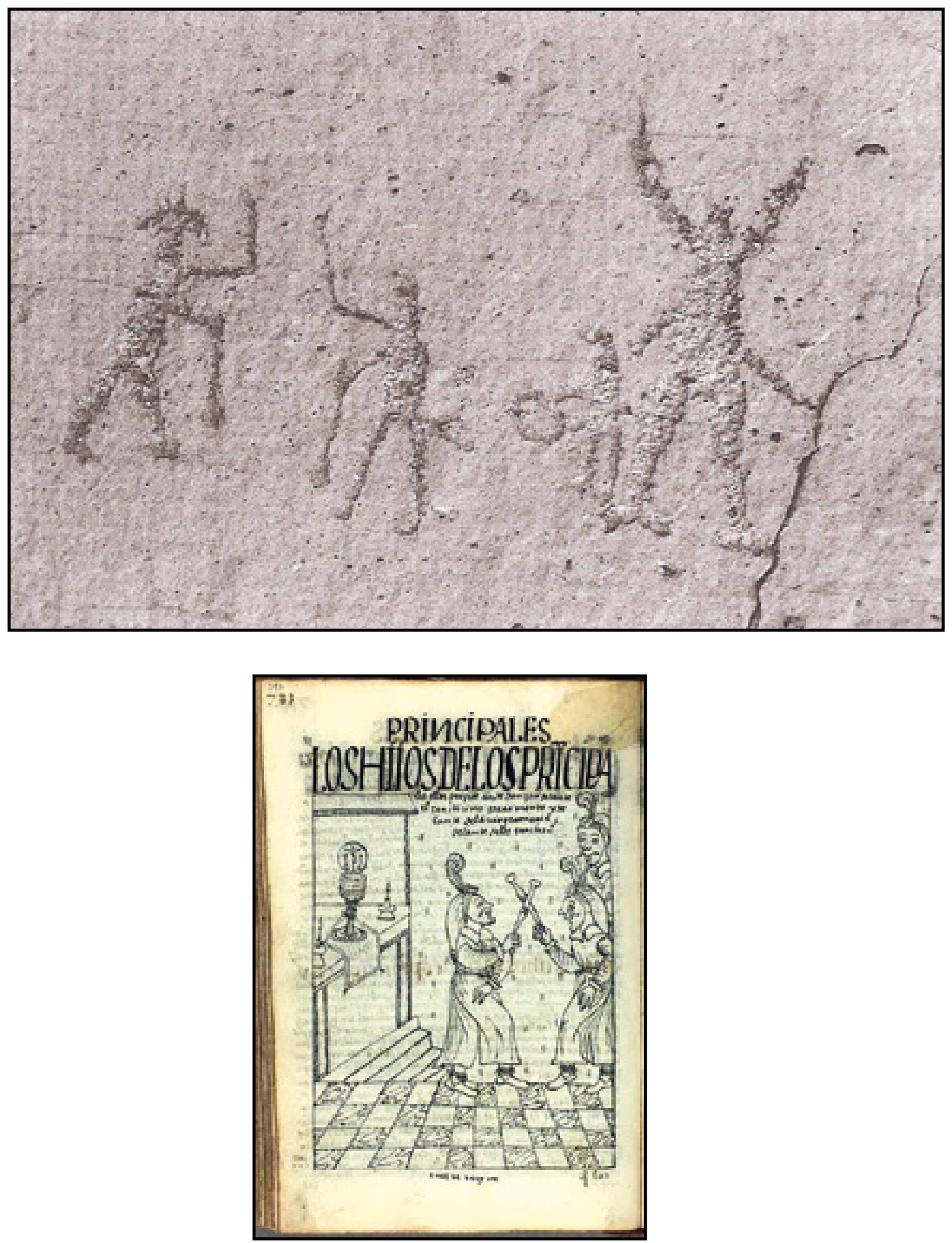

Figura 17. a) Posible grabado de un baile religioso colonial en el sitio de Purilactis-2, sector norte de la cuenca del salar de Atacama (según Núñez 2004: 40); b) Baile religioso de los hijos de autoridades andinas ante las imágenes cristianas (Guaman Poma, f. 783; en http://www.kb.dk/permalink/2006/poma/797/es/image/?open=id2691642). 
procesos de evangelización en la cuenca del salar de Atacama, los cuales, a partir de una readecuación colonial, mantendrían su vigencia hasta la actualidad (Núñez, 2004).

Es dable destacar que este grabado se observa hasta el momento como una representación rupestre única en todas las cuencas comentadas en este trabajo. En las tierras altas, como el caso del sitio de Chirapaca (Provincia Los Andes, La Paz, Bolivia), entre otros, se han identificado varios bailes en técnica de pintura. Respecto a personajes portando alas, en ese mismo sitio se han identificado representaciones de chatripullis (hombres ángeles) (al respecto ver Taboada, 1992, p. 151). La idea de determinadas comunidades de sentido, expresada al inicio de este trabajo, a través de la cual procesos comunicativos acerca de la vida colonial podían circular ya fuera a nivel de significantes o de temáticas compartidas, se refuerza notablemente con este sitio.
Asociado a Purilactis-2, en un cruce de senderos internodal sin asentamientos asociados, se observa un conjunto de petroglifos formativos. En la pared vertical de la quebrada y en una disposición aislada respecto de dichos grabados, se elaboraron en algún momento de la Colonia dos cruces calvario (Figura 18). Una de ellas presenta una base triangular y una segunda, una base que desarrolla la forma de un arco o cúpula con dos trazos lineales interiores. Hay restos coloniales superficiales como fragmentos de gruesas botellas trasformadas en raspadores (L. Núñez, com. pers. a J. L. Martínez, 2016).

En este mismo sector septentrional del oasis, se ubica también el sitio Los Arrieros 1, en el cual, junto a representaciones rupestres diagnosticadas como de la fase Solor (900-1450 DC) y manifestaciones coloniales, tales como el motivo ecuestre temprano (Núñez et al., 1997, p. 321), se ha identificado el grabado de un ave, probablemente un gallo (Figura 19). Este grabado pudiera o no pertenecer al período

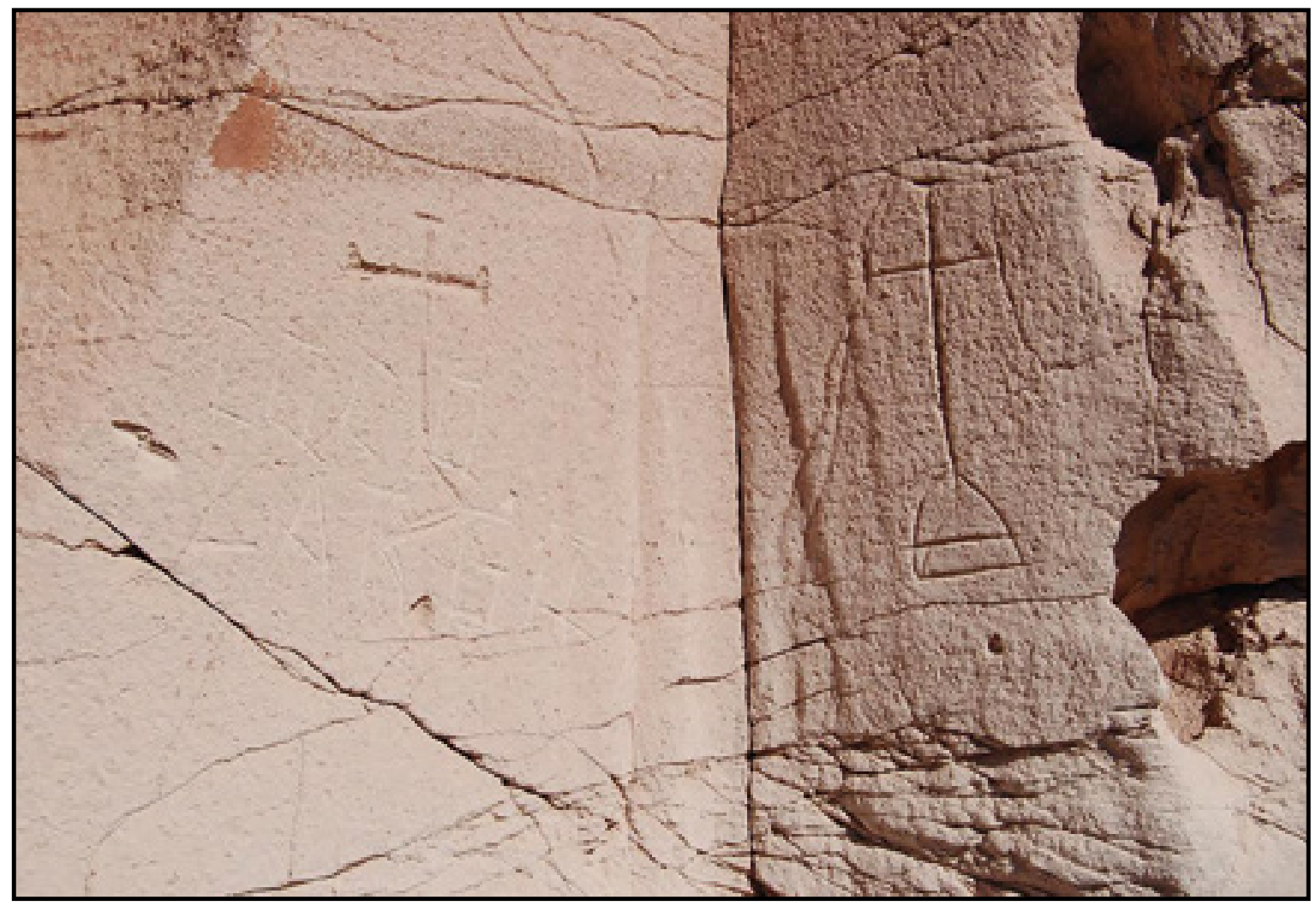

Fig. 18. Cruces calvario en una disposición aislada respecto a otros significantes andinos cerca del sitio de Purilactis-2 (fotografía gentileza L. Núñez). 


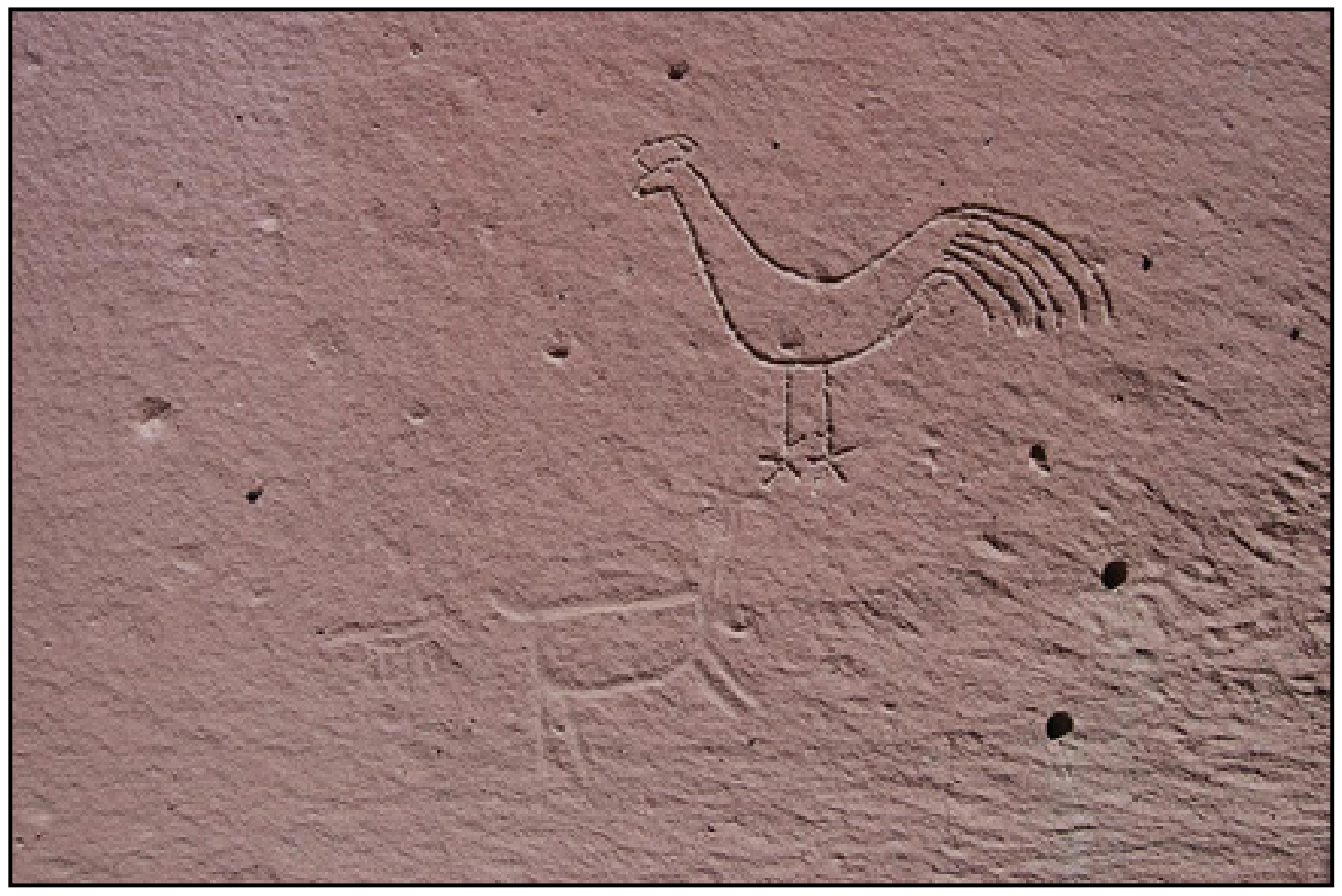

Figura 19. Grabado de un "gallo" en quebrada Los Arrieros, cuenca de Atacama (fotografía gentileza L. Núńez).

colonial, dado que el sitio fue posteriormente parte de la ruta que traía ganado argentino hacia las salitreras de la pampa (L. Núñez, com. pers. a J. L. Martínez, 2016), lo que está evidenciado en grabados con nombres de posibles arrieros y fechas del siglo XIX.

Extremo meridional del salar de Atacama. En la banda sur de quebrada Tulán, aguas abajo de las vertientes, entre corrales históricos con ocupaciones de varias épocas, se ubica el sitio de Tulán-64 (Núñez et al. 1997, p. 320). En este sitio destacan al menos tres conjuntos significantes como los únicos diseños coloniales del total de la quebrada. Los grabados se asocian a un alero y en el cual hay igualmente arte rupestre de la fase Solor (900-1450 DC), así como material republicano (Núńez et al., 1997). Por los registros fotográficos facilitados por nuestro colega, podemos observar que en un sector del alero se observan dos paneles separados por una fractura. El de la izquierda presenta cinco calvarios y tres motivos ecuestres. Se observan otros grabados de cuadrúpedos de menor tamańo, uno de los cuales parece ser la ejecución de un jinete inconcluso. En el extremo inferior derecho de este conjunto significante se observa otro cuadrúpedo con un diseño de contorno lineal. Existe la posibilidad de que todos estos motivos correspondan al período Colonial.

De los calvarios grabados destaca una cruz de base triangular con su línea basal convexa. Este motivo evoca con fuerza el calvario tallado en un tronco vivo de tamarugo en la vecina localidad de Peine (Tilomonte), y en cuyo ápice se talló la fecha de 1681. Los otros cuatro calvarios del sitio presentan bases subcirculares, observándose una interesante variación entre ellas (Figura 20).

Respecto a los motivos ecuestres, estos se orientan en ambas direcciones y en su ejecución responden a un patrón esquemático lineal, patrón que se asocia, tal como hemos discutido en otros lugares, a un momento de contacto indígena-hispano. En el panel del lado izquierdo se observa otro cuadrúpedo de contorno lineal que parece configurar un motivo ecuestre. 


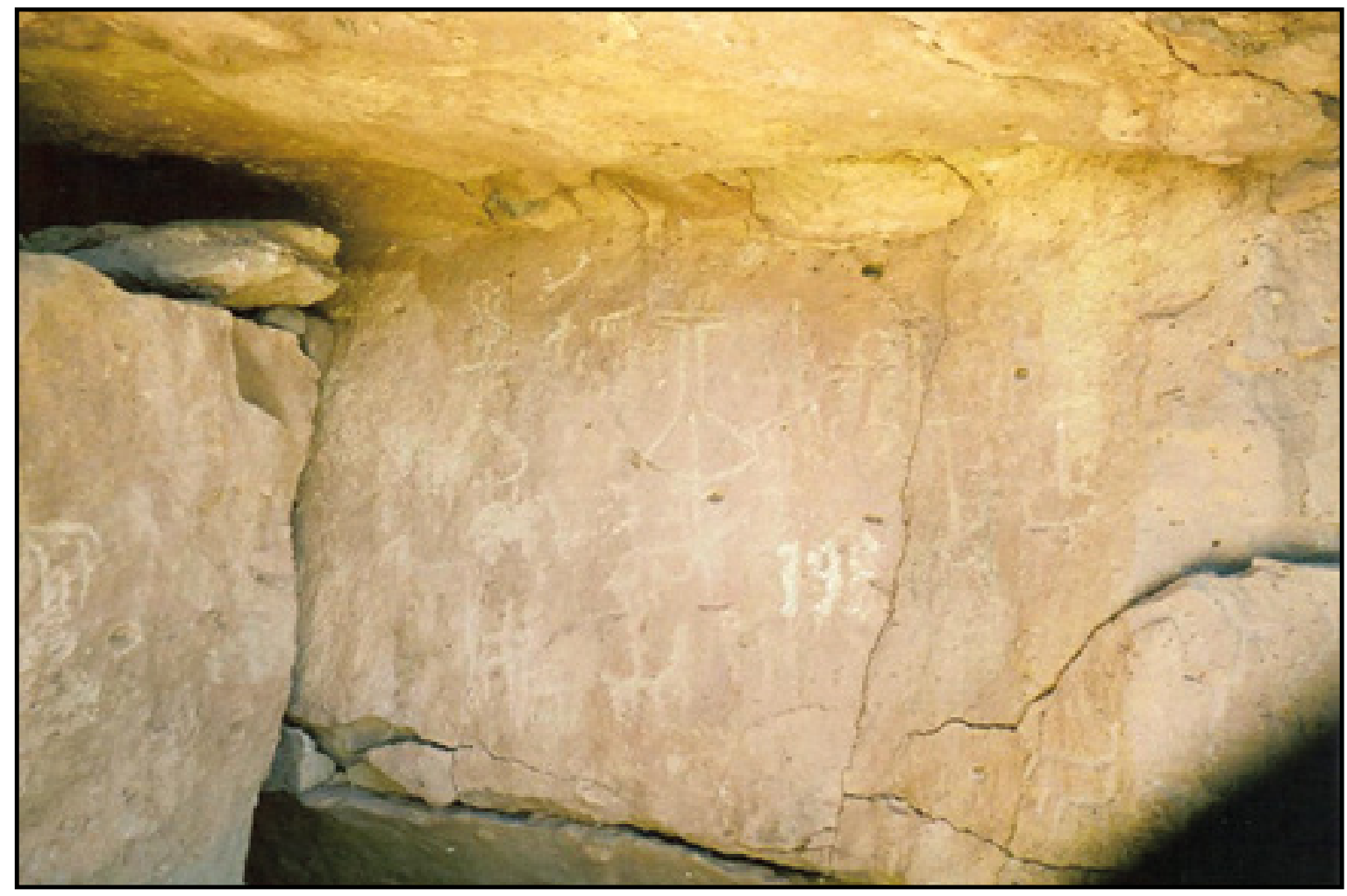

Figura 20. Motivos de cruces calvario en el sitio Tulan-64, extremo meridional del salar de Atacama (fotografía gentileza de L. Núńez).

Un tercer panel permite observar dos motivos ecuestres y otros motivos muy borrosos, entre los que se observan al menos tres camélidos esquemático lineales. El motivo ecuestre mejor conservado se configura como un camélido esquemático lineal, con el torso grabado en contorno, insinuando un vientre abultado. El jinete se construye con un par de adiciones lineales sobre el lomo del animal, terminando en un pequeño remate perpendicular, insinuando la cabeza o el sombrero de un individuo. Una proyección lineal entre el cuello largo del animal y el jinete parece representar una rienda (Figura 21).

Con estas observaciones preliminares se puede proponer que este sitio corresponde a una construcción colonial, faltando un estudio más detallado para discriminar los significantes exclusivamente coloniales de aquellos anteriores o posteriores. Con todo, se puede observar que estos contextos pueden corresponder a dos momentos históricos bien dife- renciados: aquel asociado al motivo ecuestre en su construcción colonial temprana y uno más tardío relacionado con los procesos de evangelización en el extremo sur de la cuenca del salar de Atacama. Lo interesante aquí es que, desde la perspectiva de su emplazamiento en un espacio discreto, el sitio parece más bien vinculado a actividades pastoriles (corrales) que a rutas de circulación regional.

Al sudeste del pueblo de Peine se ubica un sitio conocido localmente como Chaltukai, que consiste en un gran corral con varios bloques en su interior, algunos de los cuales están grabados con motivos de camélidos esquemáticos lineales y motivos antropomorfos. Se encuentra cerca del tambo Inka y asociado al Qhapaq Ñan que cruza por este sector hacia Tilomonte. Se trata de un bloque de regulares dimensiones en cuya cara plana se grabó una serie de dos hileras superpuestas de camélidos en perfil de factura esquemática lineal y en filas (tropa), encabezada cada una de ellas por un antropomorfo 


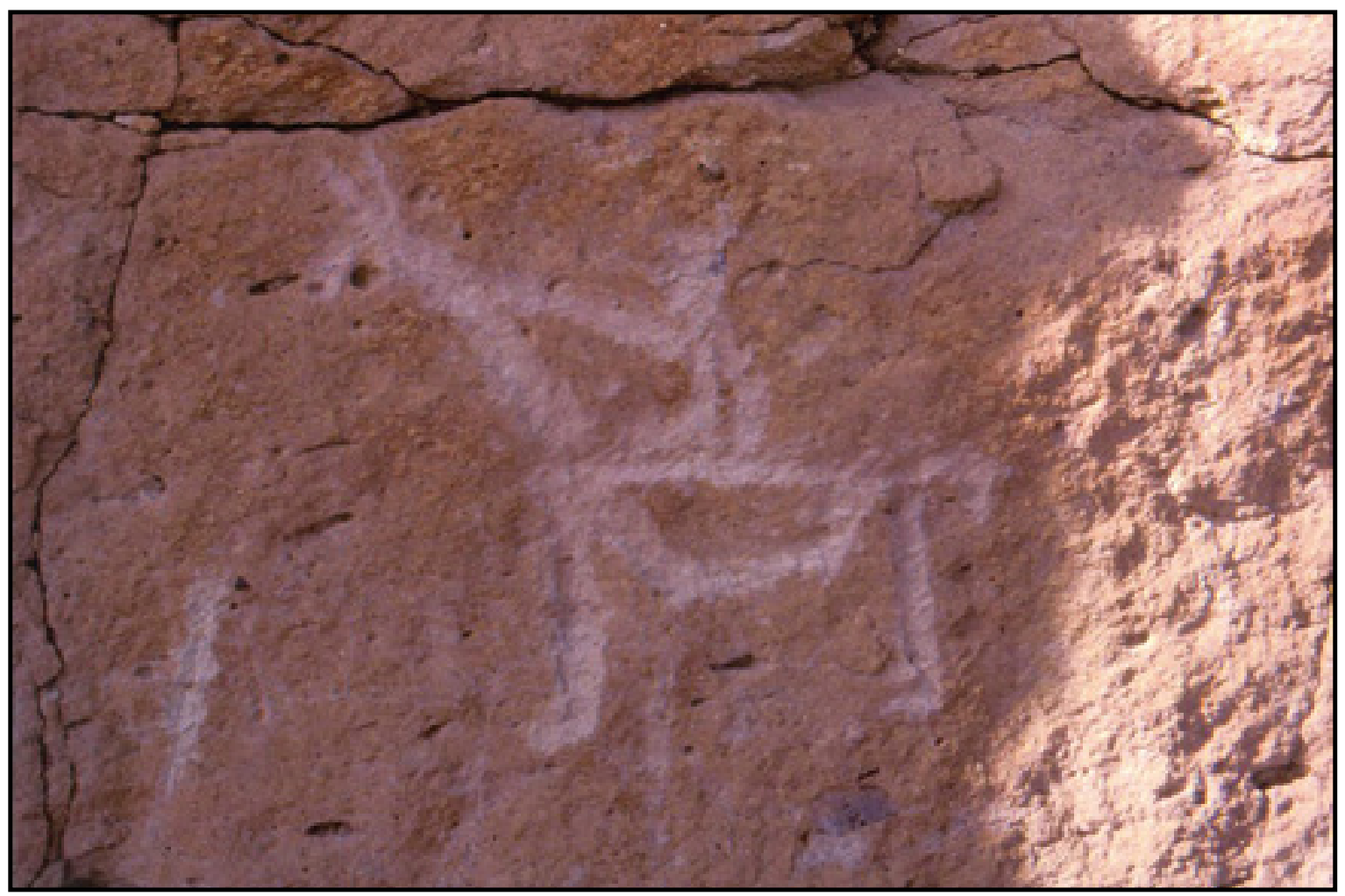

Figura 21. Detalle de motivo ecuestre con atributos de camélido con vientre abultado, sitio Tulan-64, extremo meridional del salar de Atacama (fotografía gentileza de L. Núñez).

frontal. Arriba de estos conjuntos se observan tres camélidos solitarios, el de la posición superior, en términos generales comparte los atributos formales del resto del conjunto significante, siendo rasgos singulares la adición de un trazo lineal sobre el lomo del animal y la proyección de una posible rienda, identificándose como un motivo ecuestre que por sus atributos reconocemos como un motivo colonial temprano.

En resumen, en esta cuenca volvemos a encontrar una práctica colonial indígena que se expresó en una ocupación desigual de los espacios. La mayor cantidad de sitios y de número de registros se ubica, hasta aquí, en el sector norte del salar, contrastando con los sectores central y sur de la misma cuenca. De la misma manera, el rango cronológico de ocupación de sitios con arte rupestre colonial parece ser más amplio en el sector septentrional, en el cual ubicamos registros incluso correspondientes al siglo XIX.

\section{Cuenca de Susques}

En lo que es actualmente la localidad de Coranzulí, departamento de Susques, provincia de Jujuy, Argentina, en un alero rocoso se ubica el sitio de Licante, alejado de las rutas principales de desplazamiento de las poblaciones locales. Colonialmente perteneció a la doctrina de Atacama la Alta, aun cuando la fecha de su adscripción no ha sido determinada con precisión (Rivet, 2013). En el sitio se han identificado pictografías prehispánicas, coloniales y republicanas (las marcas de arrieros ya comentadas para Atacama la Alta) y es posible que algunas de las imágenes religiosas hechas por los pobladores locales sean subactuales (Rivet, 2013, p. 19).

El sitio está compuesto por un conjunto de chullpas $^{6}$ en piedra cuyas fechas más tempranas son del

6 Las chullpas, monumentos funerarios y vinculados en muchos casos a las divinidades de los cerros, pueden tener diferentes morfologías: aéreas, semisubterráneas, 

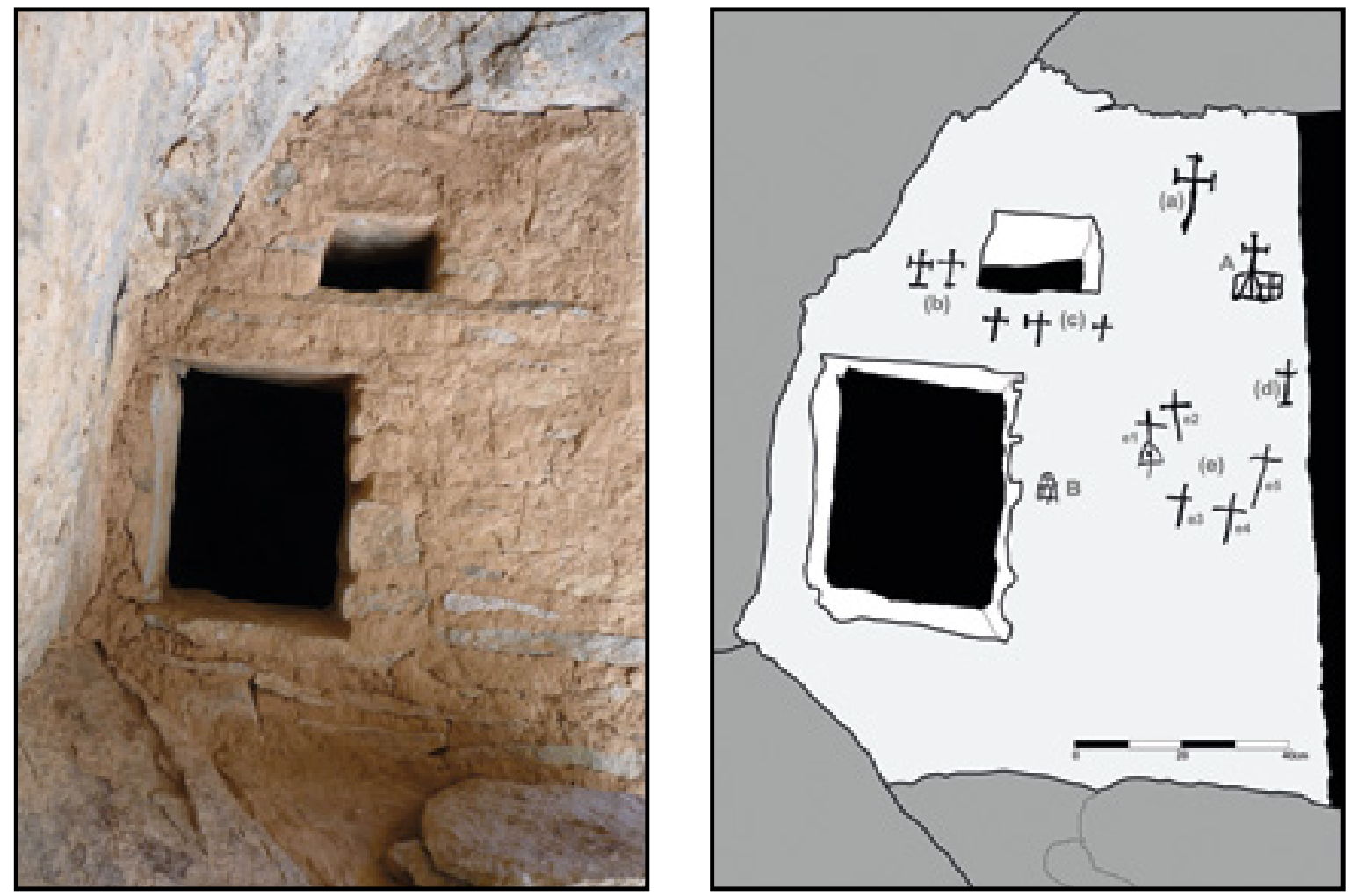

Figura 22. Representaciones cristianas en el sitio de Licante, cuenca de Susques (según Rivet, 2013). Se muestra la fachada de la "chullpa-iglesia" (fotografía gentileza de C. Rivet).

siglo XIV y las últimas llegan hasta el período republicano. Una de estas chullpas, ubicada en un nivel más alto que las anteriores, presenta características singulares de construcción, con muros de piedra revocados en barro, una puerta de acceso y una estructura ligeramente longitudinal, que han llevado a Rivet a postularla como una "chullpa-iglesia" (Rivet, 2013, p. 17). Es aquí que se encuentra un conjunto de grabados cristianos: hasta 22 cruces latinas, una cruz de calvario y dos representaciones de iglesias o arquitectura religiosa católica.

Se trata de un sitio extremadamente interesante, porque a diferencia de la tendencia general que hemos venido mostrando hasta aquí, las técnicas de ejecución en el mismo sitio son variadas. Hay grabados, pictografías hechas con carboncillo negro y lo que la investigadora denomina 'lutograbados', "realizados en la argamasa de barro fresco, conformando una

adosadas; de piedra o adobe. En este caso, se trata tanto de estructuras aéreas como adosadas a los muros del alero rocoso. suerte de 'arte mural'" (Rivet, 2013, p. 21). Si bien la iconografía es colonial, la técnica es prehispánica (Figura 22). Otra de las características del sitio es que las representaciones coloniales y republicanas respetaron las imágenes anteriores, agregándole complejidad simbólica al sitio, sin destruirlas.

Rivet (com. pers. a J. L. Martínez, 2016) nos informó del reciente descubrimiento de otro sitio, llamado Candados, también en el área de Coranzulí, en el que se identifica la figura de un jinete. Un rasgo que nos parece significativo de este sitio es que la pintura se ubica dentro de una oquedad de la roca, por lo que prácticamente no se ve a primera vista (Figuras 23a y b). 

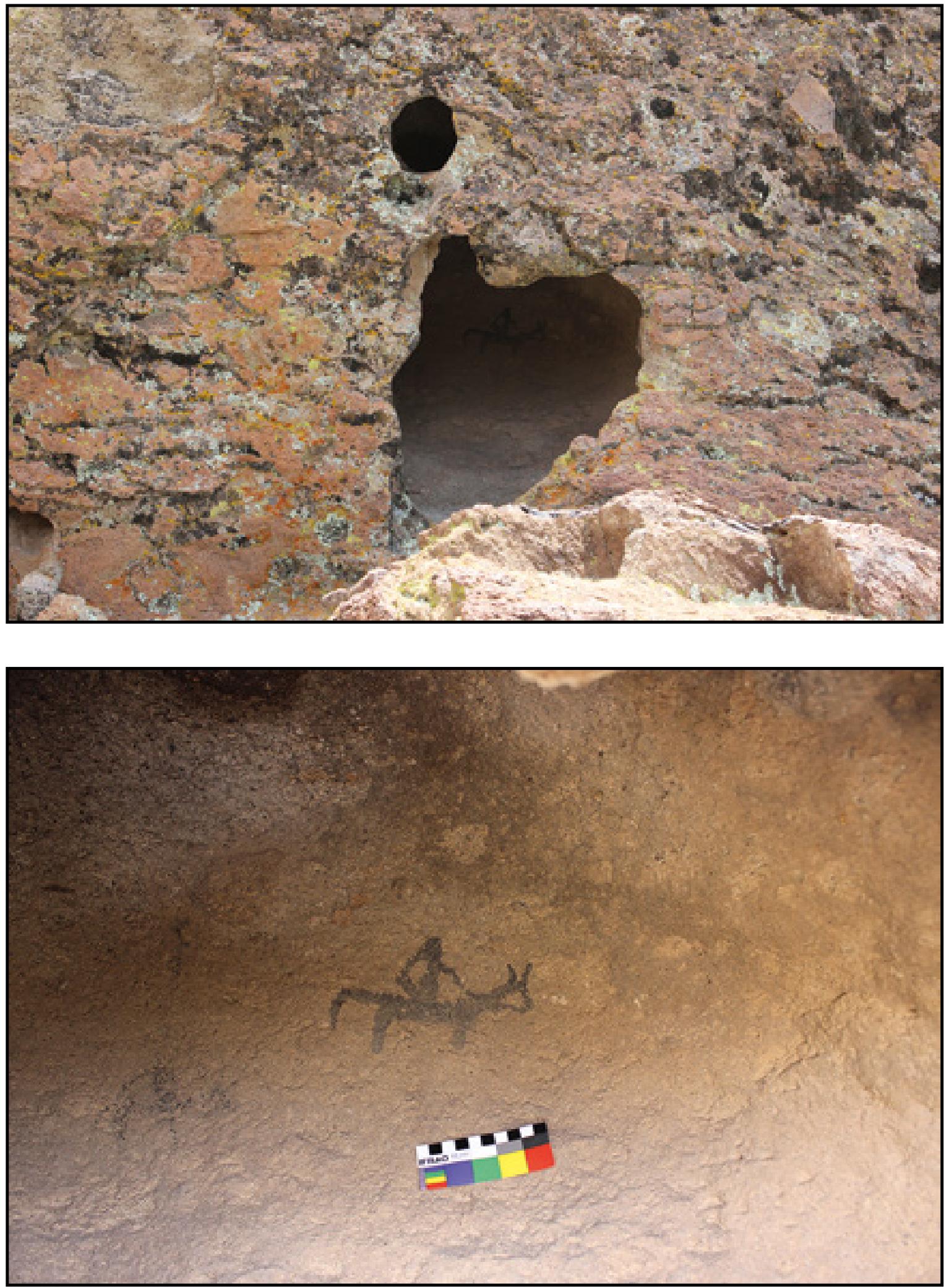

Figura 23 a y b. Jinete dentro de oquedad, en sitio Candados, cuenca de Susques (fotografía gentileza de C. Rivet). 
Discusión preliminar: la localización de los sitios de arte rupestre colonial. Espacios discretos y rutas de circulación del poder colonial (Tabla 1).

Tabla 1. Sitios con arte rupestre con significantes coloniales identificados.

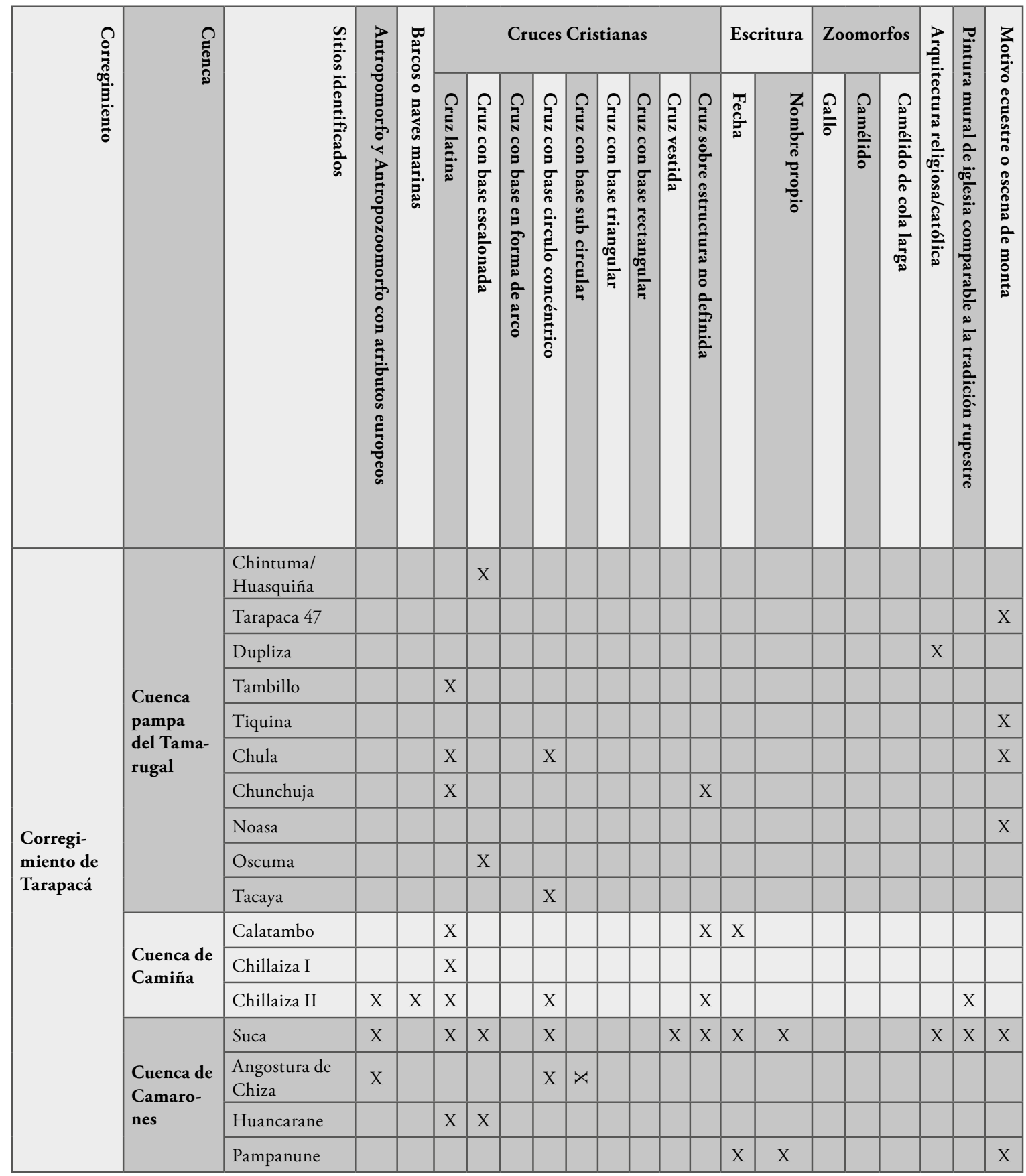




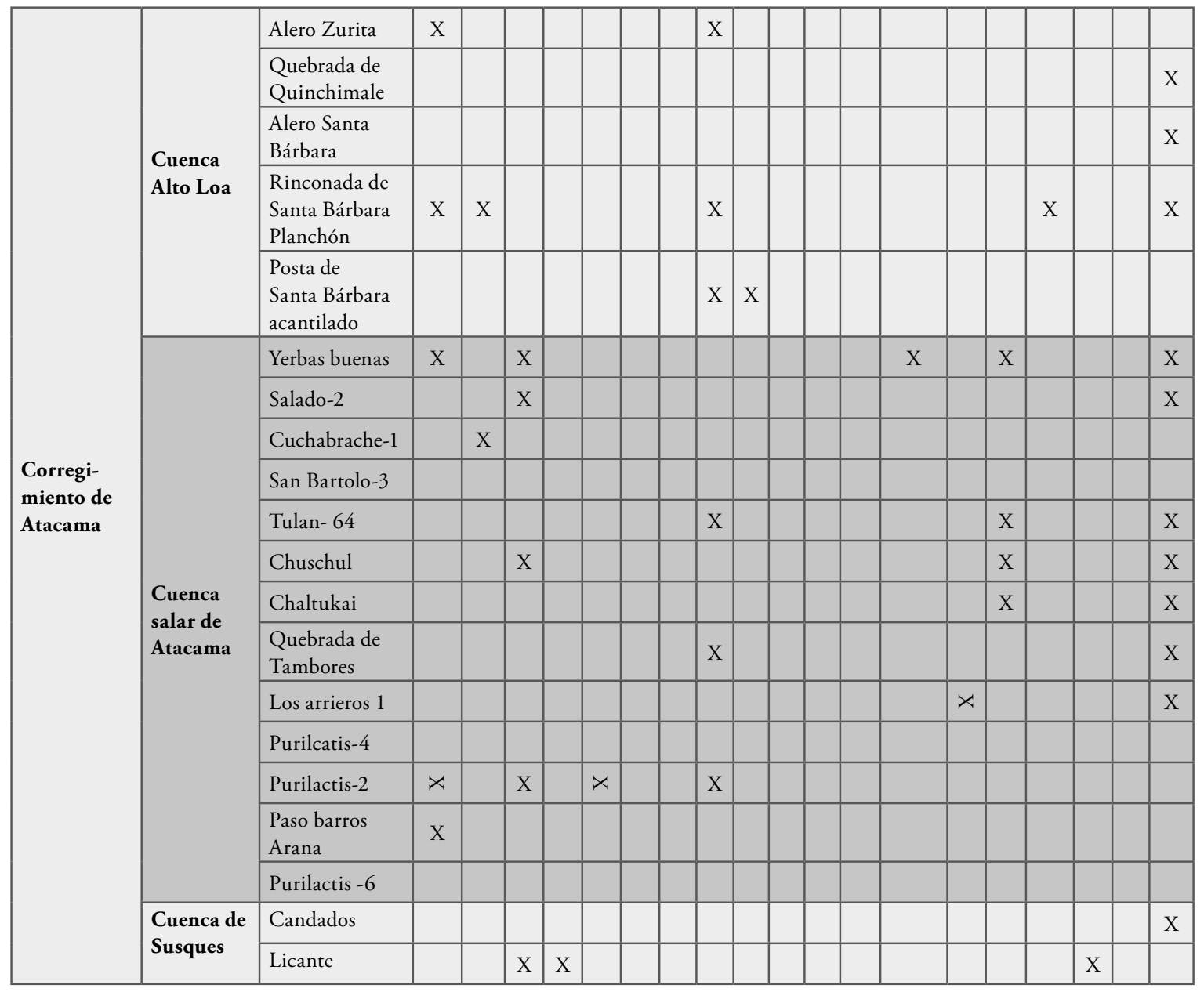

Proponemos aquí una lectura del emplazamiento espacial de los sitios con representaciones rupestres coloniales de los corregimientos de Tarapacá y Atacama, pero esta vez no desde su relación con las cuencas hidrográficas, sino con los espacios de inscripción del poder colonial, específicamente con algunas unidades de administración eclesiástica. Las diferencias identificadas podrían deberse a muchos factores, no necesariamente excluyentes. Por una parte, a las características y profundidad de la impronta colonial: a la presencia más o menos regular y activa o pasiva de los curas o corregidores, al desarrollo de actividades económicas que congregaban una presencia europea en las proximidades, tales como los caminos, postas o minas. Pero también podrían estar vinculadas a las dinámicas sociales internas de cada comunidad, a sus tamaños demográficos y a la presencia de autoridades étnicas y tradicionales re- ligiosas con capacidad de liderazgo, o a conflictos internos, divisiones y procesos de desestructuración o de continuidad de prácticas comunitarias compartidas. Finalmente, también, a las características de los procesos religiosos locales, esto es, a la mayor o menor profundidad de la evangelización y la extirpación de idolatrías; al surgimiento de "primeros católicos" andinos encargados ellos mismos de reprimir o impedir el acceso y uso de los sitios con arte rupestre; a la posibilidad de distintos modos de asimilación del cristianismo, o (¿por qué no?) a diferencias en las formas de las religiosidades andinas locales. En efecto, nada nos autoriza a pensarlas como homogéneas. Veámoslo con más detalle.

Al observar el espacio tarapaqueño, podemos ver tendencias diferenciales en su interior, tanto desde el punto de vista de la cantidad de registros como 
de la manera en que los sitios se integran y/o permanecen en el nuevo "orden" territorial impuesto en la Colonia. Si bien los dos curatos entre los cuales estaba dividida la población indígena manifiestan una cantidad similar de sitios asociados, la relación entre esos sitios, los centros administrativos, religiosos o económicos coloniales y las rutas de circulación, es muy distinta en cada caso. En Tarapacá se observa una concentración espacial mayor que en Camiña. La distancia entre los sitios y las sedes del poder eclesiástico en el curato de Tarapacá es poca, ellos se encuentran relativamente cercanos a lo que fue Tarapacá Viejo y la reducción construida en la segunda mitad del siglo XVI en la ladera opuesta de la quebrada. También se encuentran cercanos a Huarasiña, lugar donde se habría asentado el tenientazgo y donde habría tomado posesión Lucas Martínez Vegazo, el primer encomendero de la región.

Este patrón es distinto en el caso de Camińa, donde observamos una mayor distancia entre los sitios y el lugar donde se habría asentado la parroquia, que está asociado al sitio arqueológico Camiña-1 y el actual poblado de Camiña, en la parte superior de la quebrada. En este caso, los sitios también se encuentran distantes de los pueblos intermedios. Hasta el momento no se observan sitios con representaciones rupestres coloniales en relación a Chiapa y Sotoca, que fueron localidades intermedias en el sistema de administración eclesiástico. Similar distribución espacial se presenta entre los sitios Suca y Angostura de Chiza, que se encuentran distantes de Miñi-Miñi y Miñita, como también del pueblo de Codpa hacia el norte.

En el territorio atacameño colonial los patrones de ubicación parecen mostrar las dos posibilidades ya descritas. Si bien, en general, tanto los sitios del Alto Loa (en Atacama la Baja) como los de Atacama la Alta se encuentran igualmente alejados de los principales centros poblados del período (Chiu Chiu y San Pedro de Atacama, respectivamente, cabeceras administrativas y religiosas), en lo que respecta al sitio Ayquina, este se ubica tan solo a un kilómetro del poblado de reducción colonial y que parece haber desempeńado un papel centralizador en el proceso de evangelización local (Martínez C., 2010). En el sitio Tulán-64, en el extremo meridional de la cuenca del salar de Atacama, se observa una anti- gua tradición rupestre en un contexto de ecorrefugio (sensu Núñez, Cartagena, Carrasco, De Sousa y Grosjean, 2006), denotando la persistencia colonial del sistema en las lógicas ancestrales de la inscripción rupestre en las paredes de la quebrada. En el caso del alero Licante, este se ubica aproximadamente a 10 $\mathrm{km}$ lineales del poblado de Coranzulí, a su vez una pequeñísima localidad alejada de todo centro administrativo colonial, en la puna de Atacama.

Considerando que el poder colonial no solo se expresó en asentamientos específicos, como es el caso de las unidades administrativas, sino también en rutas de circulación y santuarios de peregrinación (entre otros espacios), es importante pensar los sitios existentes en relación a dichos espacios o rutas de circulación.

En este sentido podemos ver que sitios como Angostura de Chiza, Calatambo y Chillaiza I y II se encuentran cercanos a espacios de circulación, pero en una posición de poca visibilidad y dificultad en el acceso. Si bien en el caso de Angostura de Chiza este sitio se ubica en un punto de tránsito entre la quebrada de Camarones y Chiza, este es claramente un espacio de circulación menor al existente, a poca distancia entre el sector de Cuya y Chiza, lugar donde se puede observar un geoglifo prehispánico de características monumentales, que anuncia un espacio de circulación importante.

Algo similar está ocurriendo en el nodo de Santa Bárbara, en el Alto Loa, un espacio de comunicación longitudinal entre la cuenca del Gran Salar y la pampa del Tamarugal y sus cuencas adyacentes. En sentido vertical, cruza una ruta que comunica la costa del Pacífico y las tierras altas, marcando una ruta a Potosí en tiempos coloniales. Al observar los sitios hacia el norte, al interior del cañón, se puede ver que los componentes coloniales van disminuyendo, hasta prácticamente desaparecer. La mayoría parece concentrarse entre el Alero Zurita por el norte, hasta la Rinconada de Santa Bárbara por el sur. En este espacio de circulación se marcan significantes como el motivo ecuestre y las cruces calvario de base triangular, que vemos funcionando de dos modos excluyentes entre sí. Por una parte, como se observa en el Alero Zurita, se integran en solidaridad con el sistema rupestre local; por otra, expresan un profundo 
conflicto con el mismo sistema, al funcionar como ícono de la extirpación de idolatrías en los paneles pintados y grabados en las paredes del cañón frente a la posta de Santa Bárbara. ${ }^{7}$

Al norte de la cuenca del salar de Atacama se documentan varios espacios asociados a rutas prehispánicas que comunicaban esta cuenca con la del río Loa, como los de Purilactis-2, 4 y 6 y quebrada Tambores, que comunicaban con el oasis de Calama, o los de Cuchabrache-1, Río Salado-2 y San Bartolo-3, en dirección a Caspana.

Una situación interesante la plantea el sitio $\mathrm{Tu}$ lán-64, ya comentado más arriba, y ubicado al borde suroriental de la cuenca del salar. La distancia respecto a la circulación del poder político y religioso colonial en la cuenca del salar es bastante significativa, no así su cercanía al Camino del Inca que pasa por Tilomonte en dirección al despoblado de Atacama. Por su disposición al interior de la quebrada se observa como un espacio de representación discreto, asociado a actividades pastoralistas, que, dicho sea de paso, es una actividad claramente documentada en este espacio, al menos desde el período Formativo hasta tiempos muy recientes.

En conclusión, al observar los significantes rupestres coloniales y su emplazamiento en el espacio geográfico construido por las sociedades andinas locales, observamos que muchos de ellos se ubican en rutas prehispánicas reutilizadas en contextos coloniales y republicanos; antiguas rutas que, en muchos casos, continúan en uso hasta la actualidad. Algunas de ellas pudieron asociarse a nodos de comunicación que permitieron la circulación de producciones materiales y simbólicas tales como el nodo de Santa Bárbara en el Alto Loa y el área de Suca y Chiza (Sepúlveda, 2008). Estos vinculan cuencas importantes, en el primer caso con el río Loa y el salar de Atacama y en el segundo, las de Camarones y Camińa.

7 La cueva de La Damiana, más al norte del Alero Zurita, constituye un espacio singular de manifestaciones rupestres de distintos períodos. Llama la atención la importante impronta de escritura alfabética y nombres propios, algunos de los cuales pueden ser coloniales. La escritura alfabética en la lógica del sistema rupestre es un tema de discusión aún pendiente.
Simultáneamente nos encontramos con espacios de conectividad más discretos que vincularon lugares más locales, como los sitios de las quebradas endorreicas que comunicaban los espacios de Noasa y Mamińa. Otros sitios, que en otro trabajo denominamos como "nuevos" (Martínez C. y Arenas, 2009), surgidos con el orden territorial colonial, están representados por el sitio Purilactis 2, que muestra únicamente motivos coloniales.

Los procesos de ruptura y/o de continuidad se observan en sitios que vienen siendo significados y semantizados desde tiempos muy antiguos. En algunos casos parecen corresponder a los espacios de una circulación local que, a ratos, parece haber escapado a los controles europeos, pero que formó parte constitutiva igualmente de la construcción de la vida social andina durante ese período. También continúan funcionando algunos espacios más "discretos", generalmente distantes de las llamadas reducciones o pueblos de indios creados por el nuevo ordenamiento territorial o las rutas que los conectaban. Responden a lugares de estar y propiciar una sacralidad transformada políticamente. Este "comportamiento" nos está enunciando una adecuación del sistema visual andino en el nuevo orden impuesto por los conquistadores europeos, y confirma la continuidad colonial de los "espacios" de representación visual rupestre prehispánicos en el área de estudio.

Con la discusión sobre el "espacio" de representación visual rupestre, buscamos ampliar nuestra mirada en torno a una noción de soporte como una unidad mínima y discreta. Diferentes fuentes nos señalan que el sitio de arte rupestre muestra mayor versatilidad en cuanto a la forma y límite, entendiendo como soporte no ya los límites de la inscripción rupestre (p.e., panel) sino el espacio mismo altamente semantizado y densamente significado. ${ }^{8}$ La revisión preliminar que presentamos aquí nos muestra que la mayoría de los sitios se encuentran en lugares liminales. En Licante (Coranzulí), las imágenes se ubican en un alero rocoso

8 Uno de nuestros evaluadores sugirió que ampliásemos esta perspectiva analítica, ya que, efectivamente, los lenguajes visuales en las piedras no se limitan al arte rupestre. Por motivos de extensión deberemos dejarla fuera, con el sueńo de retomarla más adelante, en un próximo trabajo. 
con una obvia espacialidad significante remarcada por tratarse de un espacio sacralizado por las chullpas prehispánicas. Y en Candados (muy próximo al anterior), la pintura está literalmente dentro de una oquedad. Algo similar ocurre con el Alero Zurita, una concavidad en la pared rocosa de la quebrada o con la Cueva de la Damiana y con los sitios de Angostura de Chiza, Calatambo y Chillaiza 1 y 2, todos ubicados en sectores de difícil acceso. Aleros rocosos, afloramientos de piedras o peñas, angosturas y quebradas, punkus y qaqas en una organización andina del espacio (Cruz, 2006) son lugares que marcan una suerte de "rupturas" dentro de un espacio mayor; un paisaje que para muchas poblaciones andinas formaba parte de una experiencia sensible, que permitía las relaciones con otras entidades, como algunas divinidades, o espacios y tiempos permeables, como el ukhu pacha. ${ }^{9}$

¿Por qué representar temas coloniales y, en especial, temas religiosos cristianos, en esos lugares? En trabajos anteriores (Martínez C., 2009; Arenas y Odone, 2015) postulamos que podría tratarse de un proceso de apropiación, de incorporar selectivamente nuevos significantes religiosos a los sitios propios, ya cargados de significación. Pensamos que estamos en presencia de una dimensión que integra para sí parte del poder reconocido en el dios de los cristianos y que refuerza, posiblemente, la eficacia simbólica de los ritos en el contexto de la cultura propia (sensu Arenas y Odone, 2016, p. 145). El sugerente trabajo de Rivet alienta esta posibilidad interpretativa.

Más allá de esta dimensión sacra del espacio rupestre, los significantes y conjuntos significantes que le acompañan parecen resultar de unas prácticas de selección y apropiación, que permitieron integrar al sistema rupestre local un conjunto acotado de significantes tales como el motivo ecuestre, las cruces latinas y de calvario con su variedad de bases, cam-

9 Punkus (literalmente "puerta" en quechua) y qaqas (un tipo de peñas que irrumpen en el paisaje, de coloración diferente o extraña) son actualmente "elementos que se demarcan en el paisaje altoandino tanto por sus características morfológicas como por su capacidad para comunicar diferentes espacios y mundos" (Cruz, 2006, p. 35). Uno de esos espacios es el ukhu pacha, tiempo y espacio "de adentro", de la interioridad del mundo y de la tierra; también el espacio del pasado andino. panarios de iglesias, antropomorfos portando cruces y otros con sombrero de copa y alón. Se trata de significantes que están dando cuenta de las nuevas relaciones de poder impuestas por los europeos y, por tanto, de nuevos temas que se textualizaron en los espacios sacralizados como parte constitutiva y no exclusiva del soporte rupestre. La construcción de la alteridad, el poder bélico del español, el poder de la evangelización y los conflictos inherentes a estos acontecimientos y procesos han quedado fijados para siempre en el sistema visual rupestre en los territorios de ambos corregimientos coloniales. Pero también constatamos la presencia de significantes que responden más bien a las dinámicas locales de la vida colonial de esas poblaciones. La presencia de mandoncillos y posibles rebeldes tupacamaristas, la ejecución de determinados bailes, así como las inscripciones de embarcaciones, propio de poblaciones con contacto con el espacio costero, muestran también el gran dinamismo de las representaciones rupestres, que parecen haber acogido la variedad de experiencias coloniales.

La posibilidad dinámica de construir nuevos significantes y de que estos circularan o fueran representados simultáneamente por distintas comunidades humanas, apelando a sus viejas técnicas para configurar los nuevos textos, sugiere fuertemente esa comunidad de sentido de la que hablamos inicialmente, como parte de un proceso mayor de producción de significación y comprensión del hecho colonial por parte de las poblaciones de los corregimientos de Tarapacá y Atacama. Para ello proponemos, como marco teórico, que esa producción de significación y comprensión puede ser abordada como una semiosis andina colonial (Verón, 1988), que se produjo fundamentalmente a nivel de las comunidades locales que continuaron utilizando los sistemas de registro y comunicación propios de las sociedades andinas, para enfrentar nuevas necesidades coloniales.

\section{Agradecimientos:}

Este trabajo es resultado del proyecto FONDECYT 1130431 y debe un reconocimiento especial a nuestros colegas y amigos, Lautaro Núnez, quien compartió generosamente con nosotros sus materiales y reflexiones; Luis Briones, sin el cual no hubiéramos 
podido saber de muchos de estos sitios, y Carolina Rivet, quien también contribuyó con materiales fotográficos inéditos y nuevas informaciones sobre algunos sitios. A todos ellos gracias por su enorme sabiduría y apoyo y por el desprendimiento y afecto. Agradecemos, también, el apoyo y la generosidad de Diego Aramayo por mostrarnos antiguas rutas y senderos de San Pedro de Atacama y de Yeraldy Díaz por la elaboración de la cartografía. Agradecemos particularmente a nuestra colega Daniela Valenzuela y su proyecto FONDECYT 1111063 que financió una parte del trabajo de campo en Huancarane y Chillaiza, como también al Proyecto FONDART "Evangelización del paisaje andino y arte rupestre colonial en Tarapacá" de González, Briones y Mén$\operatorname{dez}(2014)$.

\section{Referencias citadas}

Advis, P. (1990). La doctrina de Tarapacá en el siglo XVI (Perfil administrativo-eclesiástico). Revista Camanchaca, 12-13, 76-92.

Amat y Juniet, M. de (1947 [1761-1776]). Memoria de Gobierno. Rodríguez Casado, V. y Pérez, F. (Eds.). Sevilla.

Arenas, M. A. (2011). Representaciones rupestres en los Andes coloniales. Una mirada desde el sitio Toro Muerto (Comuna de La Higuera, Coquimbo, Chile). Tesis para optar al título de Antropólogo. Universidad Academia de Humanismo Cristiano, Santiago.

Arenas, M. A. (2013). Significantes coloniales del sitio Toro Muerto, Chile: Canon descriptivo y comentario preliminar. Boletin SIARB, 27, 87-104.

Arenas, M. A. y Martínez C., J. L. (2009). Construyendo nuevas imágenes sobre los Otros en el arte rupestre andino colonial. Revista Chilena de Antropología Visual, 13, 17-36.

Arenas, M. A., Lima, M. P., Tocornal, C. y Alvarado, L. (2015). El arte rupestre de Q'urini, Oruro - Bolivia. Informe de avance. Boletín SIARB, 29, 28-50.

Arenas M. A. y Odone, M. C. (2015). Cruz en la Piedra. Apropiación selectiva y circulación de una imagen cristiana en el arte rupestre andino colonial. Estudios Atacameños. Arqueologia y Antropología Surandinas, 51, 137-151.
Arenas, M. A. y Odone, M. C. (2016). Despliegues visuales en instalaciones religiosas de los Andes del sur: Una reflexión desde el arte rupestre colonial y la etnohistoria. $\mathrm{Bo}$ letin del Museo Chileno de Arte Precolombino, 21(1), 63-78.

Arkush, E. (2014). Soldados históricos en un panel de arte rupestre, Puno, Perú: los caudillos del siglo XIX y el comentario político andino. Chungara. Revista de Antropología Chilena, 46(4), 585-605.

Berenguer, J. (1999). El evanescente lenguaje del arte rupestre en los Andes atacameños. En Berenguer, J. y Gallardo, F. (Eds.). Arte Rupestre en los Andes de Capricornio (pp. 9-56). Santiago: Museo Chileno de Arte Precolombino.

Berenguer, J., Aldunate, C., Castro, V., Sinclaire, C. y Cornejo, L. (1985). Secuencia de arte rupestre en el Alto Loa: una hipótesis de trabajo. En Aldunate, C., Berenguer, J. y Castro, V. (Eds.). Estudios en Arte Rupestre (pp. 37-108). Santiago: Museo Chileno de Arte Precolombino.

Berrojalbiz, F. (Ed.). (2015). La vitalidad de las voces indigenas. El arte rupestre del contacto y en sociedades coloniales. Oaxaca: Instituto de Investigaciones Estéticas, Universidad Nacional Autónoma de México.

Bollaert, W. (1975 [1860]). Descripción de la Provincia de Tarapacá. Norte Grande, 1(3-4), 459-479.

Castro, V. (2009). De idolos a santos. Evangelización y religión andina en los Andes del sur. Santiago: Fondo de publicaciones Americanistas Universidad de Chile - Centro de Investigaciones Barros Arana, Dibam.

Chacama, J., Briones, L. y Santoro, C. (1992). Arte Rupestre posthispano: una Aproximación al Problema en el Norte de Chile. En Sociedad de investigación del arte rupestre de Bolivia (Ed.). Arte Rupestre Colonial y Republicano de Bolivia y Paises Vecinos (pp. 168-171). La Paz: SIARB.

Cruz, P. (2006). Mundos permeables y espacios peligrosos. Consideraciones acerca de punkus y qaqas en el paisaje alto andino de Potosí, Bolivia. Boletín del Museo Chileno de Arte Precolombino, 11(2), 35-50.

Cruz, P. (2012). El mundo se explica al andar. Consideraciones en torno a la sacralización del paisaje en los Andes del sur de Bolivia (Potosí, Chuquisaca). Indiana, 29, 221251. 
Gallardo, F. (2005). Notas sobre la construcción de la imagen en el arte rupestre. Boletín de la Sociedad Chilena de Arqueología, 38, 45-51.

Gallardo, F. (2009). Sobre la composición y la disposición en el arte rupestre de Chile: consideraciones metodológicas e interpretativas. Magallania, 37(1), 85-98.

Gallardo, F., Castro, V. y Miranda, P. (1990). Jinetes sagrados en el desierto de Atacama: un estudio de arte rupestre andino. Boletín del Museo Chileno de Arte Precolombino, 4, 27-56.

González, B. (2014). Discursos en el paisaje andino colonial: reflexiones en torno a la distribución de sitios con arte rupestre colonial en Tarapacá. Diálogo Andino, 44, 75-87.

Guaman Poma de Ayala, F. (1616). Nueva corónica y buen gobierno. Copenhague: Biblioteca Real de Copenhague. Recuperado de http://www.kb.dk/permalink/2006/ poma/info/es/frontpage.htm

Hernández Llosas, M. I. (2006). Inkas y españoles a la conquista simbólica del territorio Humahuaca: sitios, motivos rupestres y apropiación cultural del paisaje. Boletín del Museo Chileno de Arte Precolombino, 11(2), 9-34.

Hidalgo, J. (2011). Redes eclesiásticas, procesos de extirpación de idolatrías y cultos andinos coloniales en Atacama: XVII y XVIII. Estudios Atacameños. Arqueología y Antropología Surandinas, 42, 113-152.

Hidalgo, J. (2014). Historia andina en Chile. Vol. II. Politicas imperiales, dinámicas regionales y sociedades indigenas. Santiago: Editorial Universitaria.

Hostnig, R. (2004). Arte rupestre post colombino de la Provincia de Espinar, Cusco, Perú. Boletín SIARB, 18, 40-64.

Martínez, G. (1983). Topónimos de Chuani. ¿Organización y significación del territorio? Anthropologica, 1(1), 51-84.

Martínez C., J. L. (1998). Pueblos del chañar y el algarrobo. Los atacamas en el siglo XVII. Santiago: Dibam - Facultad de Filosofía y Humanidades Universidad de Chile.
Martínez C., J. L. (2009). Registros andinos al margen de la escritura: el arte rupestre colonial. Boletín del Museo Chileno de Arte Precolombino, 14, 9-35.

Martínez C., J. L. (2010). 'Somos resto de gentiles': el manejo del tiempo en tres comunidades atacameñas. Estudios Atacameños. Arqueología y Antropología Surandinas, 39(1), 57-70.

Martínez C., J. L. y Arenas, M. A. (2009). Problematizaciones en torno al arte rupestre colonial en las áreas centro sur y meridional andina. En Sepúlveda, M., Briones, L. y Chacama, J. (Eds.). Crónicas sobre la Piedra: Arte Rupestre en las Américas (pp. 129-140). Arica: Sociedad Chilena de Arqueología - Universidad de Tarapacá.

Martínez C., J. L. y Arenas, M. A. (2011). Los petroglifos del sitio de Tarapacá 47 y su contribución a la Comprensión del arte rupestre colonial andino. En Hubert A., González, J. A. y Pereira, M. (Eds.). Temporalidad, Interacción y Dinamismo Cultural. Homenaje a Lautaro Núñez Atencio (pp. 151-162). Antofagasta: Universidad Católica del Norte.

Martínez C., J. L. y Arenas, M. A. (2015). Iglesia en la piedra: representaciones rupestres y evangelización en los Andes del sur. En Berrojalbiz, F. (Ed.). La vitalidad de las voces indigenas: arte rupestre del contacto y en sociedades coloniales (pp. 299-325). Oaxaca: Universidad Autónoma de México.

Mege, P. (2000). Originales contra la fuerza. Boletín de la Sociedad Chilena de Arqueología, 30, 41-47.

Mege, P. y Gallardo, F. (2006). Soluciones semióticas y pinturas rupestres en la localidad del río Salado, Desierto de Atacama, Chile (manuscrito en poder de los autores).

Moragas, C. (1996). Manifestaciones rupestres en el tramo bajo de la quebrada de Tambillo. Provincia de Tarapacá. I Región. Chungara, 28(1-2), 241-252.

Murra, J. (1980). Versión Paleográfica de una Autoepiscopal de Cuzco del 24 de abril del año 1571 (Ms.).

Niemeyer, H. (1961). Excursiones a la sierra de Tarapacá. Arqueología, toponimia, botánica. Santiago. Apartado de la Revista Universitaria de la Universidad Católica de Chile. Año XLVI. 
Niemeyer, H. (1968). Petroglifos del río Salado o Chuschul (San Pedro de Atacama, Dpto. del Loa, Provincia de Antofagasta, Chile). Boletín de Prehistoria de Chile, 1(1), 85-92.

Niemeyer, H. y Schiappacasse, V. (1981). Aportes al conocimiento del período tardío del extremo norte de Chile: Análisis del sector Huancarane del valle de Camarones. Chungara, 7, 3-103.

Núñez, L. (2004). La Tirana del Tamarugal. Antofagasta: Ediciones de la Universidad Católica del Norte.

Núñez, L. y Briones, L. (1967-1968). Petroglifos del Sitio Tarapacá $\otimes 47$ (Provincia de Tarapacá). Estudios Arqueológicos, 3/4, 43-75.

Núñez, L., Cartajena, I., Loo, J., Ramos, S., Cruz, T. y Cruz, T. (1997). Registro e investigación del arte rupestre en la Cuenca de Atacama (Informe Preliminar). Estudios Atacameños, 14, 307-325.

Núñez, L., Cartagena, I., Carrasco, C., De Sousa, P. y Grosjean, M. (2006). Emergencia de comunidades pastoralistas formativas en el sureste de la Puna de Atacama. Estudios Atacameños. Arqueología y Antropologia Surandinas, 32, 93-117.

Odone, C. (1995). El tejido de las estrategias de distribución y circulación espacial en Tarapacá: un registro colonial. Memoria Americana, 4, 57-80.

Querejazu, R. (1992). Introducción. En Querejazu, R. (Ed.). Arte rupestre colonial y republicano de Bolivia y países vecinos. Contribuciones al Estudio del Arte Rupestre Sudamericano, 3, 6-27. La Paz: SIARB.

Rivet, C. (2013). Cruces e iglesias en un contexto chullpario. Arte rupestre colonial en las tierras altas atacameñas. Nuevo Mundo Mundos Nuevos - Debates, online. Puesto en línea el 14 febrero 2013. DOI:10.4000/nuevomundo.64960
Sepúlveda, M. (2008). Pinturas rupestres de la Precordillera de Arica (norte de Chile). Re-evaluación a 40 años de la obra pionera de Hans Niemeyer. Boletín SIARB, 22, 68-79.

Sepúlveda, M., Romero, A., Guevara, L., Álvaro, L. y Briones, L. (2005). Tráfico de caravanas, arte rupestre y ritualidad en la quebrada de Suca (extremo norte de Chile). Chungara. Revista de Antropología Chilena, 37(2), 225-243.

Strecker, M. y Taboada, F. (2004). Aymara Rock Art of Lake Titicaca. Rock Art Research, 21(2), 111-125.

Taboada, F. (1988). Arte Rupestre de Chirapaca. Boletín SIARB, 2, 29-36.

Taboada, F. (1992). El Arte Rupestre Indígena de Chirapaca, Depto. de La Paz, Bolivia. Contribuciones al Estudio del Arte Rupestre Sudamericano, 3, 111-117. La Paz. SIARB,

Tamblay, J. (2004). Estilos de Arte Rupestre Atacameńo en el Sitio Arqueológico Estancia de Yerbas Buenas, Río Grande, San Pedro de Atacama, Chile. Actas del V Congreso Chileno de Antropología, 370-378. San Felipe. Colegio de Antropólogos de Chile A.G.

Urbina, S. (2014). Asentamientos, poblaciones y autoridades de Tarapacá siglos XV y XVI (ca. 1400-1572). Tesis para obtener el grado de Magíster en Historia, Universidad de Chile. Santiago.

Valcárcel, L. (1947). La rebelión de Túpac Amaru. México D.F.: Fondo de Cultura Económica.

Verón, E. (1988). La semiosis social. Barcelona: Gedisa.

Walker, C. (2014). The Tupac Amaru Rebellion. London: The Belknap Press of Harvard University Press. 
